Article

\title{
Agricultural Biodiversity and Ecosystem Services of Major Farming Systems: A Case Study in Yayo Coffee Forest Biosphere Reserve, Southwestern Ethiopia
}

\author{
Mezgebu Senbeto Duguma ${ }^{1, *}$, Debela Hunde Feyssa ${ }^{2}$ and Lisa Biber-Freudenberger ${ }^{3}$ (i) \\ 1 Agroforestry, Oromia Agricultural Research Institute, Bako 03, Ethiopia \\ 2 Natural Resources Management, Jimma University; Jimma 307, Ethiopia; feyssahunde@yahoo.com \\ 3 Center for Development Research, Bonn University, Genscherallee 3, 53113 Bonn, Germany; \\ lfreuden@uni-bonn.de \\ * Correspondence: mezgebedink2001@gmail.com; Tel.: +251-910614681 or +251-929427098
}

Received: 21 November 2018; Accepted: 29 December 2018; Published: 7 March 2019

\begin{abstract}
Farming systems, with their concerns of biodiversity, ecosystem services, and productivity and production issues towards progress in human needs, wellbeing, and sustainable development, are challenging in most biosphere reserves. In this study, we assess the levels and trends of the agro-biodiversity and ecosystem services of different farming systems in the Yayo Biosphere Reserve in Ethiopia. Interviews with a total of 120 farmers, 16 key informants, and 12 focal group discussions (FDGs) were conducted, and species composition was assessed based on data collected on ten plots per major farming system. Result indicate that four farming systems, namely homegardens (HG), plantation coffee (PC), semi-forest coffee (SFC), and annual crop production (CP) systems, can be identified. Shannon and Evenness indices were highest in the HG system $\left(\mathrm{H}^{\prime}=3.14, \mathrm{E}=0.8\right)$, and lowest in the $\mathrm{CP}$ system $\left(\mathrm{H}^{\prime}=0.71, \mathrm{E}=0.18\right)$. Additionally, more diversified and relatively less cultivated farming systems provide more ecosystem services, and land users tend to practice less diversified farming systems in order to increase food supply at the expense of other ecosystem services. Therefore, this study recommends that diversified farming systems need to be considered to conserve or enhance specific ecosystem services in ways that reduce their negative tradeoffs.
\end{abstract}

Keywords: agro-biodiversity; biosphere reserve; ecosystem services; farming systems

\section{Introduction}

The agricultural practices of different farming systems, including their productivity and production, agro-biodiversity, environment, and related ecosystem services' issues towards the progress in human wellbeing and needs, and sustainable development, are challenging in biosphere reserves. Humans' wellbeing depends on ecosystems. "A farming system (FS) describes the structure and management of an agricultural production system dynamically arranged (designed) by the farmer and depending on his goals of production, priority of needs, and the regime of resources under specific natural, social and economic conditions" [1]. The global agricultural productivity (GAP) report in 2016 indicated that long-term global trends show a growing demand for food and agricultural products. At the same time, sustainable agriculture must not only satisfy human needs, but also conserve the natural resource base and sustain the economic viability of agriculture [2].

Many authors have argued that human wellbeing and progress towards sustainable development are vitally dependent upon improving the management of the Earth's ecosystems to ensure their conservation and sustainable use [3,4]. They also state that although demands for ecosystem services such as food, shelter, and clean water are growing, human actions are, at the same time, diminishing the 
capability of many ecosystems to meet these demands. In Ethiopian montane rainforests, economically valuable fountains of biodiversity are vanishing at accelerating rates due to diverging private and social net benefits from land conversion [5]. Land conversion is economically rational for farmers to convert forests into agricultural land and thereby improve their incomes. There are dynamic trends of ecosystem services and multiple agro-biodiversity practices throughout the various ecological zones and agricultural landscapes.

Ethiopia has four biosphere reserves and more than 80 forest priority areas [6], both characterized by a high level of interaction between humans and the environment. However, different farming systems can be found in both reserves, which are likely to differ regarding species composition, spatiotemporal structures of vegetation, biodiversity levels, and ecosystem functions and services $[3,7,8]$. In this study, we assessed farming trends, practices, and ecosystem services of different farming systems in the Yayo Biosphere Reserve, where especially coffee-based agricultural practices are common. The Yayo Coffee Forest Biosphere Reserve covers 167,021 ha, with the most important land cover types being forest, agricultural land, wetland, and grazing land. The whole landscape is part of the Eastern Afromontane Biodiversity Hotspot, which is one of the 34 globally important and yet threatened areas for biodiversity conservation [9]. The forest areas are further categorized into undisturbed natural forest, semi-forest coffee systems, managed for coffee production, and old secondary forests. These forests have local importance for coffee, spices, honey, and wood production. They also have regional and even international importance for the provision of ecosystem services through watershed protection (run-off control, water infiltration, soil retention) in the Nile Basin. The agricultural land consists of mainly smallholder farms with diverse crops and homegardens [9].

Yayo Biosphere Reserve is one of the habitats for diversity of Coffea arabica L., 1753 and, hence, is important for in situ conservation of the genetic diversity of the natural coffee. Coffee alone contributes around $70 \%$ of households' income in the area [10]. Data from 10 years ago indicated that over 150,000 people are living in the transition areas, deriving their livelihoods from semi-forest coffee production system in the buffer zone and different agricultural practices, including coffee plantation and home and forest gardens in the transition area [9].

Biosphere reserves attempt to reconcile environmental protection with sustainable development. However, according to Coetzer et al. [3], the reality of implementing dual 'conservation' and 'development' goals of the biosphere reserve model by UNESCO's Man and the Biosphere Programme $(\mathrm{MAB})$, is challenging due to intensified and crop production-based agricultural activities of humans in the protected areas. Fragmentations of natural and cultural landscapes by anthropogenic actions in most tropical rain forests are likely to cause significant changes in agro-biodiversity and ecosystem functioning [11]. Yet, while we know that farming practices affect species numbers and compositions, our understanding of the specific impacts of these changes on the ecosystem functioning is very limited.

This study contributes to the understanding of different farming systems on the globally important ecosystems of Yayo forest and beyond. The results are relevant for the evidence-based implementation of sustainable and diversified farming practices in the Yayo Coffee Forest Biosphere Reserve and other protected areas.

\section{Materials and Methods}

\subsection{Description of the Study Area}

The research was conducted in four kebeles of the Yayo Coffee Forest Biosphere Reserve, namely Wabo and Bondawo Magala within the Yayo district and Wangegne and Gaba within the Hurumu district, situated in the Ilu Abba Bora Zone of the Oromia National Regional State, Southwestern Ethiopia (Figure 1). The Kebeles were selected based on their proximity to the biosphere reserve, which belongs to the center of origin of Coffea arabica [12]. Yayo BR is the largest and most important forest for the conservation of the wild populations in the world [9], and the area plays a key role in the conservation of the wild coffee populations and other species. It is located between latitude $8^{\circ}$ 
$0^{\prime} 42^{\prime \prime}$ to $8^{\circ} 44^{\prime} 23^{\prime \prime} \mathrm{N}$ and longitude $35^{\circ} 20^{\prime} 31^{\prime \prime}$ to $36^{\circ} 18^{\prime} 20^{\prime \prime} \mathrm{E}$ [9]. The biosphere reserve includes Eastern Afromontane Biodiversity Hotspot and Important Bird Areas of international significance, and is also of high cultural and historical significance with many archaeological sites, ritual sites, caves, and waterfalls. The Yayo Coffee Forest Biosphere Reserve has three different management zones, namely core area, buffer zone, and transition area. The transition zone alone, where agricultural activity is dominant, occupies $70.5 \%$ of the total area of the biosphere reserve [9].

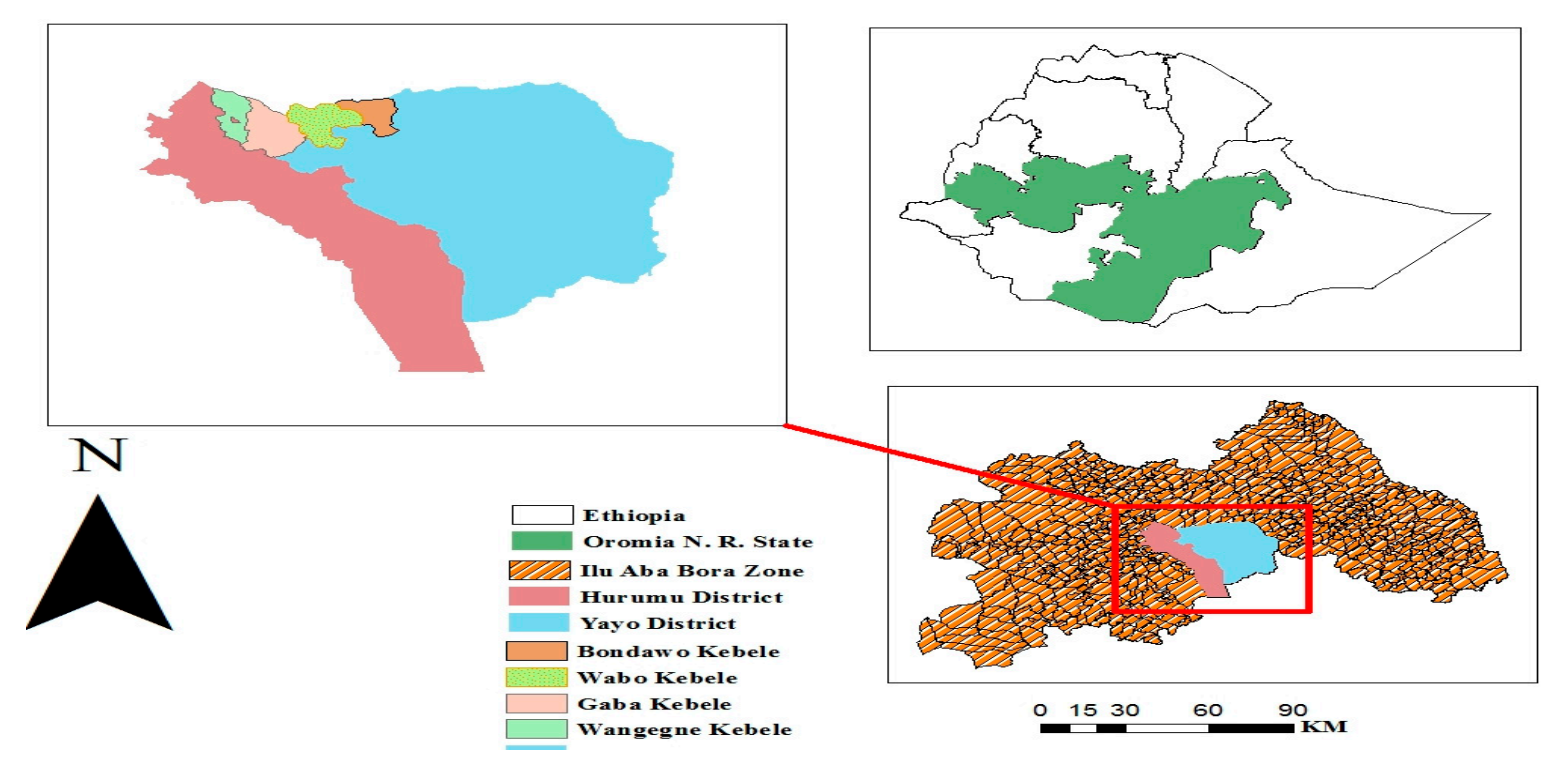

Figure 1. Map and location of study site, July 2017.

\subsection{Identification of Farming Systems}

There are many different farming systems being practiced within the Yayo Coffee Forest Biosphere Reserve. However, identifying the most practiced and major farming systems were important for the current study. Accordingly, major farming systems were identified based on interviews with representatives of government authorities in the study area and personal visits during narrative walks. 'Narrative walks', a qualitative method to collect grounded data according to Jerneck and Olsson [13], were used in this study to explore the social and natural dimensions of the complex and diverse natural, cultural, and agricultural landscapes of the subsistence agriculture in the area. Based on interviews with the government authorities in the area, such as the Agricultural Offices of Yayo and Hurumu districts, the Oroimia Forest and the Wild Life Enterprise of Ilu Aba Bora Branch, and the Environment and Coffee Forest Forum of Yayo area, we identified four major farming systems, namely homegardens (HG), plantation coffee (PC), semi-forest coffee (SFC), and annual crop production (CP) systems. Farmers were, for each field data collection activity, selected based on these interviews.

\subsection{Assessments of Species Diversity}

We assessed species diversity and the ecosystem service provisioning of different farming systems for the four identified farming systems. For this purpose, farmers were selected using stratified random sampling of farmers from four kebeles (villages), Bondawo Magala and Wabo kebeles of Yayo, and Gaba and Wangegne Kebeles of Hurumu districts. Following Chiarucci et al. [14], we assessed crop diversity on 10 plots with a size of $20 \times 20 \mathrm{~m}$ plot (or $400 \mathrm{~m}^{2}$ equivalent for linear areas). Ten plots were sampled for each farming system (Tables A1-A5).

Shannon diversity $\left(\mathrm{H}^{\prime}\right)$ and evenness index $\left(\mathrm{H}^{\prime} / \mathrm{LN}(\mathrm{S})\right)$ were used to assess species diversity and their distribution in each major farming system. Species compositions (Species Richness_S) and their diversity index (Shannon_H' and Evenness_H' $/ \mathrm{Ln}(\mathrm{S})$ ) were computed for the four major farming systems. This was based on 10 plots for each system to identify the linkage between agro-biodiversity 
and ecosystem services. The formula for this index is $\mathrm{S}=-\sum(\mathrm{Pi} \log (\mathrm{Pi}))$ with $\mathrm{Pi}=\mathrm{ni} / \mathrm{N}$, where $\mathrm{N}$ is the total number of individuals in a sample, ni are the individuals of species I, and A is the total number of species observed.

\subsection{Assessment of Status and Trends of Ecosystem Service Provisioning}

The contribution of each farming system to ecosystem service provisioning, as well as its trends, were assessed based on structured interviews with selected farmers from the four identified farming systems.

Interviews were conducted with 120 respondents from the households of 1815 in the 4 kebeles. The number of the respondents, $n$, was determined by the Kothari Formula (1) [15].

$$
n=\mathrm{z}^{2} \times \mathrm{p} \times \mathrm{q} \times N /\left(\mathrm{e}^{2}(\mathrm{~N}-1)+\mathrm{z}^{2} \times \mathrm{p} \times \mathrm{q}\right)
$$

where $N$ equals the size of the total population.

Assuming a standard variation of $\mathrm{z}=1.96$, a sample proportion $\mathrm{p}=0.1$, a probability for $\mathrm{q}=0.9$, and an acceptable error $\mathrm{e}=0.05$, a sample of 120 respondents were selected. Other criteria for the selection of respondents referred to their age (between 45 and 65 years), or if they were committee members of any local management unit, a model farmer a local elder, or an active farmer who had been practicing at least three of the four major farming systems. Using these criteria, we wanted to make sure that respondents were being selected that were experienced enough to recall their farming practices and their access to ecosystem services from the past 30 years.

The United Nations Millennium Ecosystem Assessment [16,17] provided the first consistent ecosystem services classification scheme, which served in this study as the basis for assessing the status of different ecosystems and their capacity to support human wellbeing. Based on structured interviews, trends of perceived ecosystem services from the major farming/cropping systems during the last 30 years in the selected villages/kebeles were collected. We focused our study on the period of 30 years to capture the trends of ecosystem service provisioning before and after the establishment of the biosphere reserve in 2009.

For the purpose of the interview, we defined and specified the four major ecosystem service categories (provisioning, regulatory, cultural, and supporting services) as particular services, such as for example, food, water, fuelwood, fodder, and genetic resource (Table A1). The respondents were asked based on Likert-scale questions to remember and describe the importance of the services they have received from the farming systems between 1987 and 2016 in 10-year intervals (1987-1996, 1997-2006, and 2007-2016) (Table A1). Additionally, they were asked for additional information about their own perception of the biosphere reserve.

\subsection{Collection of Supporting and Checkup Information}

In the four villages (Bondawo Magala, Wabo, Gaba, and Wangegne) 12 focus group discussions (FGDs) and a total of 16 key informant interviews were undertaken. The key informants included experts, model farmers, and members of the biosphere reserve management unit. Additionally, we conducted three FGDs with 6 to 8 randomly selected group members for each village. In total, 83 local community members participated in the group discussions ( 6 members in each of 5 FGD, 7 members in 3 of each FGD and 8 members in each of 4 FGDs).

For all structured interviews and species compositions data part, descriptive statistics of SPSS tool version 20 (IBM, New York, NY, USA), Past version 3 Øyvind Hammer, Oslo, Norway), and Microsoft Excel version 16 (MS, Redmond, WA, USA), were used as analyzing tools. Trends of ecosystem services (ES) were assumed from the frequencies of respondents on the relative importance. 


\section{Results and Discussion}

\subsection{Major Farming Systems}

Key informant interviews indicated that the biosphere reserve is suitable for multiple farming systems and known for its high levels of agro-biodiversity. We found that four major farming systems are the most commonly practiced in the study area: homegarden agroforestry system (HG), plantation coffee system (PC), semi-forest coffee production system (SFC), and annual crop production system $(\mathrm{CP})$.

\subsubsection{Homegarden Agroforestry System}

The homegarden system is the second most common farming system in the area. While most farmers are familiar with this system, the size and species compositions may vary from farmer to farmer (Figure 2). The crops of homegardens range from herbs, tubers, and roots, such as cabbage, anchote (Coccinia abyssinica (Lam.) Cogn.), godare (Colocasia esculenta (L.) Schott) to larger fruit and shade trees, like mango (Mangifera indica L.), avocado (Persea Americana Mill.), Grevillea robusta A.Cunn. ex R.Br., and Cordia africana. Additionally, most of the homegardens have dense stands of trees, including coffee, enset (Ensete ventricosum Lam.), and khat (Catha edulis (Vahl) Forssk. ex Endl.) (Table A2). In line with Muhamad et al. [18], we found that agroforestry plays an important role to conserve natural forests, thereby improving the livelihoods of local people and perceived as the source providing the most ecosystem services, followed by forest, and this finding indicated that agroforestry plays an important role as a compensating product of forest resources.

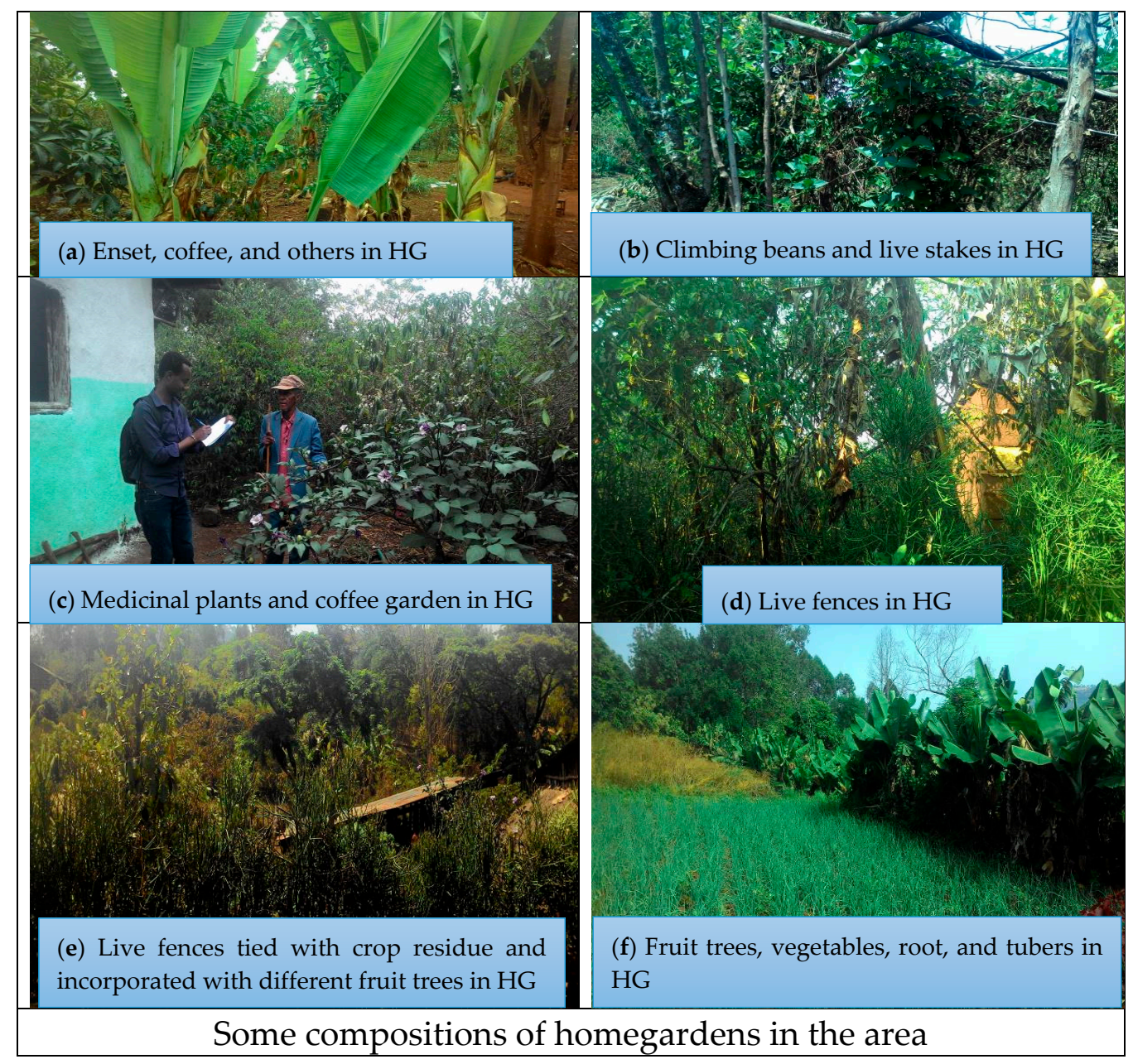

Figure 2. Homegardens (HG) and some compositions of them taken by the author, March 2017. 


\subsubsection{Plantation Coffee System (PC)}

The plantation coffee system (PC) is a highly productive and intensively managed coffee farming system located in the buffer zone, transitional zone, and also in the homegardens of the area. Plantation coffee systems and semi-coffee forest production are very similar, but differ in terms of species composition and natural tree species components. While plantation coffee is a monoculture with lower levels of tree and shrub species diversity and well-structured stands, semi-coffee production systems tend to have a higher crop diversity with more complex stands. The result of key informant interviews has pointed out that some of the oldest plantation coffee stands were established during the so-called Derg regime (the Ethiopian political system and ruling party 1974-1991), when the Coordinating Committee of the Armed Forces, Police and Territorial Army ruled Ethiopia between 1974 and 1987. Between 1984 and 1986 (1976-1978 Ethiopian Calendar), the government pushed the local communities to settle in few areas, which also made them to expand coffee plantation into some marginal forest areas and agricultural fields near the natural forest.

Personal observations and focus group discussions indicate that the plantation size coffee system has been increasing, especially since 2009, as a consequence of the BR establishment (Figure 3). This result is also supported by the documentation of the nomination of Yayo Biosphere Reserve [9], which already anticipates the expansion of the biosphere buffer zone (doubling its size in the next decade), where plantation coffee systems managed by individual farmers are mostly located in the transition area. This trend has been supported by planting programs for coffee and indigenous shade trees, where these programs were implemented by governmental and some local and non-governmental organizations.
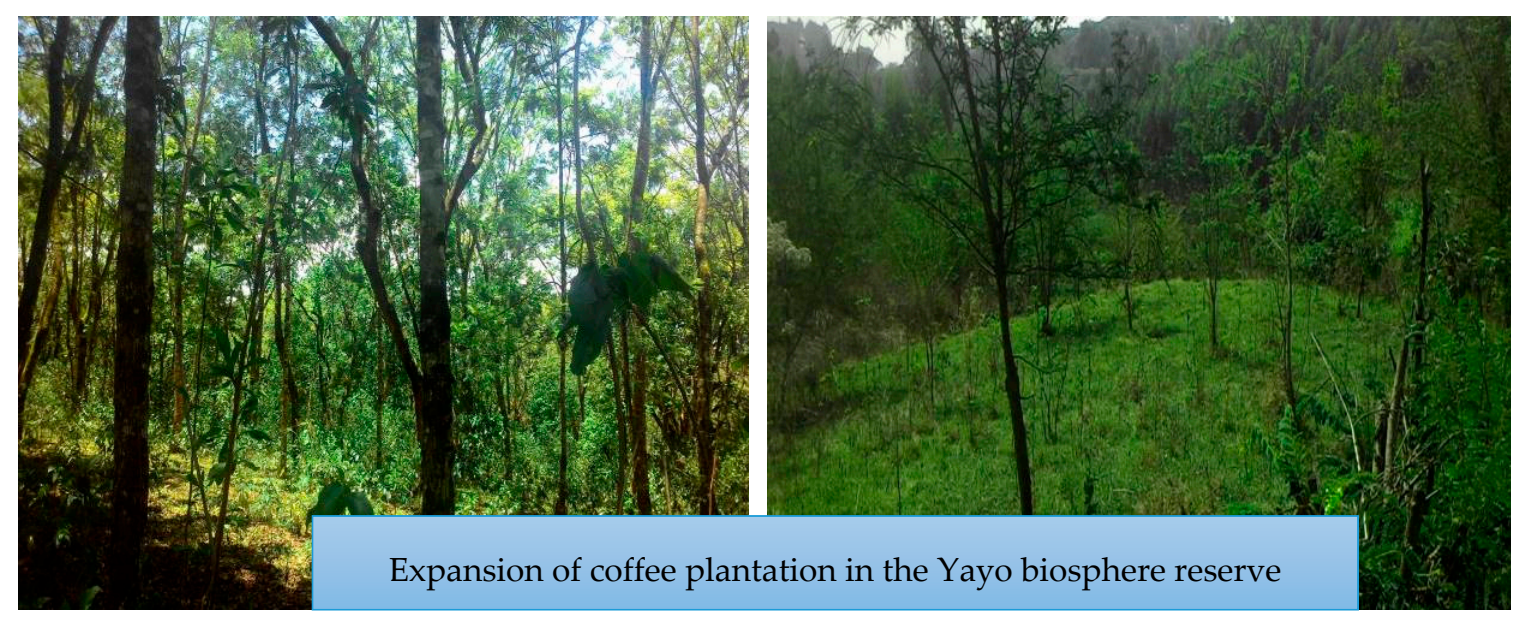

Figure 3. Photographs illustrating expanding trends of coffee plantation in the Yayo BR, photo taken by the author, March 2017.

\subsubsection{Semi-Forest Coffee Production System (SFCS)}

Semi-forest coffee production systems represent the oldest and most common farming system in the study area, known for their unique traditional coffee production practices. Coffea arabica is indigenous to the understory of the moist evergreen montane rainforest of Ethiopia $[19,20]$. Traditionally, coffee is produced by managing natural forests and coffee plants of wild origin in the SFC system. According to [20], this traditional method of coffee cultivation is a driver for preservation of indigenous forest cover, differing from other forms of agriculture and land use, which tend to reduce forest cover. This system has been distinguished from plantation coffee system by its dense tree and shrubs species compositions mixed with complex stands of coffee plants. We observed more indigenous tree diversity and denser understory components than in plantation coffee (Table A4). Semi-forest coffee is harvested from semi-wild plants in forest fragments, where farmers thin the upper canopy and annually slash the undergrowth. In traditional practice, farmers clear some shade 
trees and understory vegetation, which are competing with coffee, but maintain a combination of tree seedlings, shrubs, climbers, shade or multipurpose trees, and coffee plants (Figure 4). This result is supported by Gole et al. $[9,19]$ which indicated that, in areas where the density of coffee plants is low, wild seedlings are picked from unmanaged forest and planted in gaps. Wild Coffea arabica shrubs are dominant in the system.

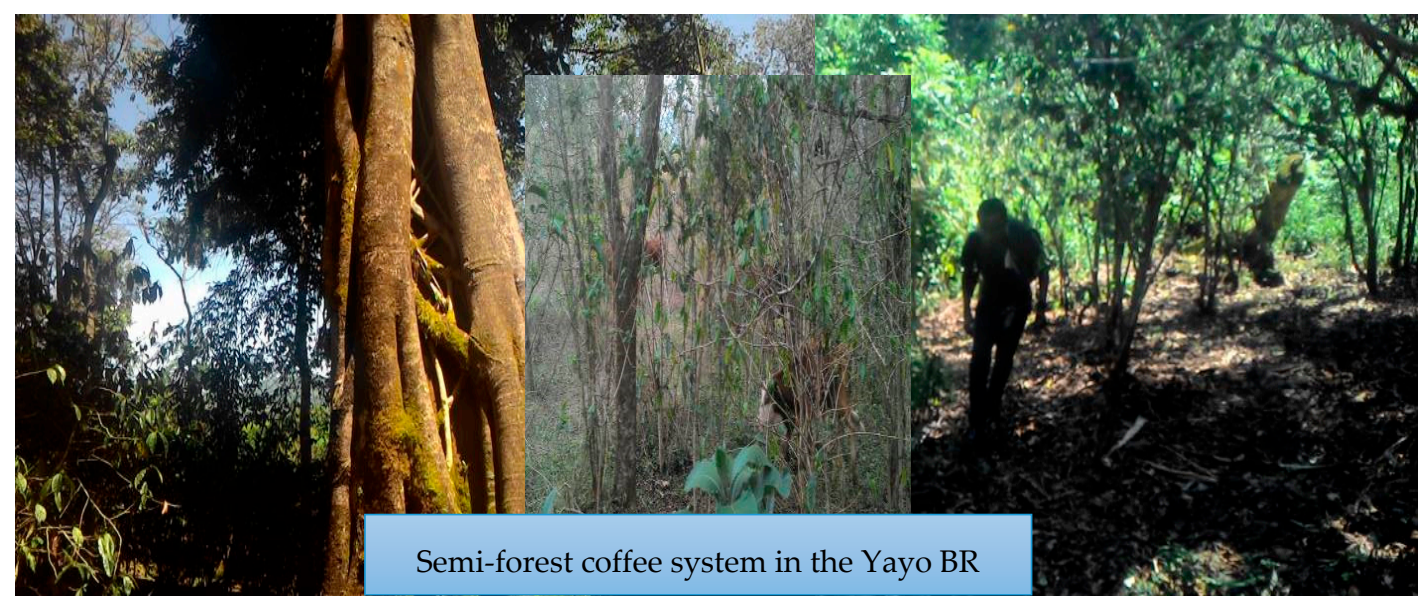

Figure 4. Pictures of semi-forest coffee production systems in the Yayo BR, photo taken by the author, April 2017.

\subsubsection{Annual Crop Production Systems}

In the transitional areas of the biosphere reserve, annual crop production (maize (Zea mays L.), sorghum (Sorghum versicolor Andersson), millet (Eleusine indica (L.) Gaertn.), teff (Eragrostis tef (Zucc.) Trotter), wheat (Triticum aestivum L., 1753), nug (Guizotia abyssinica (L.f.) Cass.), etc. (Table A5)) and perennial crops such as chat (Catha edulis) and coffee are common. We also observed woodlots, live fences, and boundary tree plantations, remnants of some indigenous tree and shrub species, and some forest patches in the system (Table A5). Furthermore, relative to the other farming systems in the area, the CP is intensively managed with some soil and water conservation activities being practiced in most fields (Figure 5). Annual crop production as key staple food for a majority of the human population [21] is of crucial importance for the food supply of the study area.

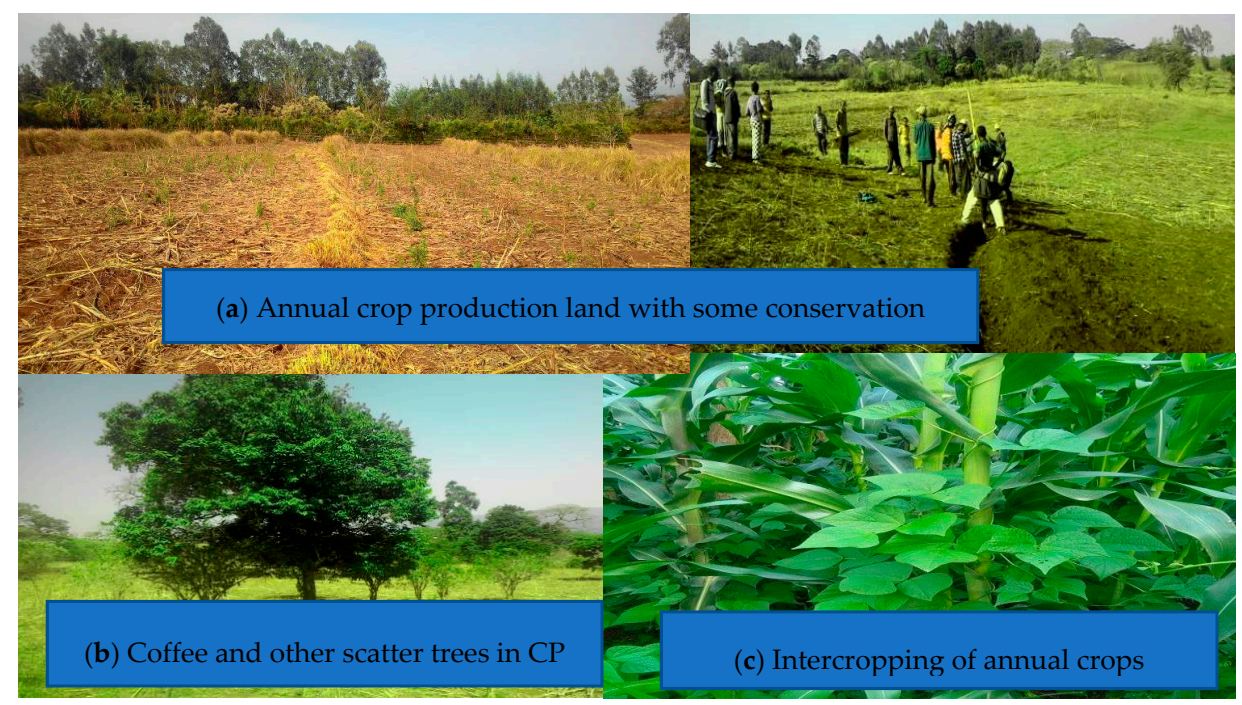

Figure 5. Annual crop production (CP) fields observed in Yayo BR photo taken by the author, April 2017. 


\subsection{Agro-Biodiversity within the Major Farming Systems}

This study identified the links between agro-biodiversity and ecosystem goods and services, their overall benefits, and scenarios. In this study, agro-biodiversity refers to the variety and variability of flora that contribute to food and agriculture in the broadest sense, and the values associated with them. This is also reported by Jackson et al. [22], which stated that sometimes agro-biodiversity is considered to encompass a broader definition, to include the full diversity of all organisms living in agricultural landscapes, including biota for which function, in the human utilitarian point of view, is still unknown, where crops and livestock will be chosen by the farmer.

Species Compositions and Diversity Indices of the Farming Systems

The finding of this study revealed that the Shannon index $\left(\mathrm{H}^{\prime}\right)$ and evenness are positively correlated, while species richness (S) was not. Shannon and evenness index were highest in the homegarden system $\left(\mathrm{H}^{\prime}=3.14\right.$, Evenness $\left.=0.8\right)$, and lowest in the annual crop production systems $\left(\mathrm{H}^{\prime}=0.71\right.$, Evenness $\left.=0.18\right)$ while the species richness $(\mathrm{S})$ was highest for the semi-forest coffee system $(\mathrm{S}=56)$ and lowest for the plantation coffee system $(\mathrm{S}=28)$ (Table 1$)$.

Table 1. Diversity indices of the major farming systems indicating species richness, Shannon diversity index and evenness of species within the systems, based on 10 plots of data for each.

\begin{tabular}{cccc}
\hline \multirow{2}{*}{ Farming Systems } & \multicolumn{3}{c}{ Diversity Indices } \\
\cline { 2 - 4 } & Species Richness (S) & Shannon $\mathbf{( H}^{\prime} \mathbf{)}$ & Evenness (H'/LN(S)) \\
\hline Homegarden System & 50 & 3.14 & 0.80 \\
Plantation Coffee System & 28 & 1.21 & 0.36 \\
Semi-Forest Coffee System & 56 & 2.09 & 0.52 \\
Annual Crop Production System & 47 & 0.71 & 0.18 \\
\hline
\end{tabular}

The farming systems identified in the study area have been managed for the production of food and income (compare also with [23]); agricultural landscapes can provide a wide range of goods and services to society. 'Ecosystem services' are those functions of ecosystems being provided by different agricultural activities which may directly or indirectly depend on the agro-biodiversity components. This study also identified that the agro-biodiversity within the annual crop production and plantation coffee systems in the study area is being lost, and observed, in some areas, at an accelerating rate. This result is in line with the finding reported by OECD (Organisation for Economic Co-operation and Development) [24], which discussed the fact that biodiversity is fundamental to sustaining life, supplying critical ecosystem services such as food provisioning, water purification, flood and drought control, nutrient cycling, and climate regulation, with less concern for agro-biodiversity.

Semi-forest coffee production systems tend to have the highest species richness followed by homegardens, annual crop, and plantation coffee systems, respectively. However, the Shannon and evenness diversity indices show that the diversity of homegarden systems are the highest, followed by semi-forest coffee, plantation coffee, and annual crop production systems, respectively (Table 1). The inconsistency of the different indices indicates that, in forested landscapes, direct and indirect aspects of agroforestry management might be more important than local forest cover for species distribution [25]. Habitat loss and forest fragmentation resulting from vegetation clearing for wild coffee production, however, has been a driver of global biodiversity loss [26].

\subsection{Mapping of Ecosystem Services of the Major Farming Systems}

We found that rural people were greatly aware of different ecosystem services they have been obtaining from the different farming systems (Table 2). Provisioning services were clearer and more readily comprehensible than other services, e.g., regulating services. In this study, we compare the use and trends of ecosystem service provisioning for the different farming systems based on four main 
categories: provisioning services, regulatory services, cultural services, and supporting services [16]. Understanding the tradeoffs among ecosystem services is critical to manage ecosystems for multiple goals [27].

Agricultural practices and socio-ecological benefits are strongly interrelated, which might also affect the ecosystem services of different farming systems (Table 2). Especially, land area used for agricultural production or for other purposes, such as nature conservation, presents a tradeoff to society in terms of ecosystem services provided. Agricultural lands provide food, feed, fiber and, increasingly, biofuels, while natural ecosystems provide other important ecosystem services (Table 3).

\subsection{Ecosystem Services and Their Temporal Trends of the Major Farming Systems}

For homegardens, the importance of food provisioning decreased considerably during the last 30 years. While $85.8 \%$ of all respondents referred to this ecosystem service for the time period between 1987 and 1996, only 55.8\% mentioned it for the latest period of 2007-2016 (Table 3). Reasons for this decrease were, according to the focus group discussions, the expansion of family settlements, wild life damage, and shifts from food to cash crop and fruit tree production in homesteads. At the same time, respondents' percentage for description of food provisioning has been increased from $55 \%$ to $78.3 \%$ in plantation coffee system, and indicated almost the same through the study period in annual crop production system, which has been frequented between $98.3 \%$ to $100 \%$ (Table 3 ).

According to the percentage of respondents, there are significant tradeoffs among ecosystem services being provided by the farming systems. For instance, aesthetic value was described as very high (100\%) in semi-forest coffee system and it was the least (only $2.5 \%$ ) in annual crop production while food provision trend was opposite (100\% for annual crop and only $70 \%$ for SFCS). Additionally, when the food provision of annual crop is being increased its soil formation value has been declined from 36.7 to $7.5 \%$. There are also the same tradeoffs within all systems (Table 4).

Therefore, sustainable development options need to be considered to conserve or enhance specific ecosystem services in ways that reduce negative tradeoffs or that provide positive synergies with other ecosystem services through assimilations of agro-biodiversity, improving strategies in agricultural practices. Appropriate modifications in diversified agricultural practices and adoption of a more integrated approach to ecosystem and agro-biodiversity practices must be introduced to compensate the declining trends of the ecosystem services. On the other hand, favoring people living close to forests in farming systems strategies will promote prospective biodiversity conservation and help to maintain various ecosystem services as long as people's needs will be accommodated. Additionally, ecosystem services' valuation for the farming systems and organic coffee certification must be pushed forward, and schemes rewarding systems providing more services should be introduced.

In general, the relative importance of the temporal trends of ecosystem services being provided by the major farming systems has been seen as tradeoffs (Table 4). For instance, if we assume that the result of the first period (1987-1996) as a starting point and coded as a positive indicator, the spiritual service of all systems has been declining $(+--)$ at both later periods (Table 4$)$. On the other hand, climate regulation, soil formation, and habitat provisions of HG, PC and SFC systems have increased $(+++)$, and genetic resource conservation, fuelwood, aesthetic, and educational values of SFCS, for instance, show a recovery trend $(+-+)$. 
Table 2. Most important ecosystem services provided by the four major farming systems in the Yayo Biosphere Reserve.

\begin{tabular}{|c|c|c|c|c|}
\hline \multicolumn{5}{|c|}{ Major Farming Systems } \\
\hline Types of Services & Homegarden AF & Plantation Coffee & Semi-Forest Coffee & Crop Production \\
\hline \multicolumn{5}{|l|}{ Provisioning Services } \\
\hline Food production & $\begin{array}{l}\text { Fruits, tubers, vegetables, oils, } \\
\text { pulses, and roots }\end{array}$ & Wild fruits & $\begin{array}{l}\text { Wild fruits and some edible } \\
\text { leaves of shrubs and climbers }\end{array}$ & $\begin{array}{l}\text { Cereal, pulses, and } \\
\text { horticultural crops are all } \\
\text { the services }\end{array}$ \\
\hline $\begin{array}{l}\text { Biodiversity/genetic } \\
\text { resources }\end{array}$ & $\begin{array}{l}\text { Conservations of anchote } \\
\text { (Coccinia abyssinica), godare } \\
\text { (Colocasia esculenta), and Oromo } \\
\text { dinich (Plectranthus edulis (Vatke) } \\
\text { Agnew) genetic resources }\end{array}$ & $\begin{array}{l}\text { Protection of wild fruit trees } \\
\text { and the five legally protected } \\
\text { tree species }\end{array}$ & $\begin{array}{l}\text { Protection of wild fruit shrubs, } \\
\text { climbers, and the five legally } \\
\text { protected tree species }\end{array}$ & $\begin{array}{l}\text { Conservations of } \\
\text { indigenous and legally } \\
\text { protected tree species }\end{array}$ \\
\hline $\begin{array}{l}\text { Water (drinking, cooking, } \\
\text { irrigation) }\end{array}$ & & & $\begin{array}{l}\text { Source of pure streams, } \\
\text { springs, and small rivers for } \\
\text { humans and livestock }\end{array}$ & \\
\hline Fuelwood and timber & $\begin{array}{l}\text { Branches, stems, and leaves of } \\
\text { fruit trees and others } \\
\text { Crop residues }\end{array}$ & $\begin{array}{l}\text { Dried coffee stems, shrubs, } \\
\text { branches of shade trees for } \\
\text { fuelwood, and shade trees such } \\
\text { as Cordia africana for timber }\end{array}$ & $\begin{array}{l}\text { The main source of fuelwood } \\
\text { and timber production yet }\end{array}$ & $\begin{array}{l}\text { Crop residues and } \\
\text { branches of parkland trees } \\
\text { and shrubs (Cordia, Ficus, } \\
\text { Croton, etc.) }\end{array}$ \\
\hline Fodder & $\begin{array}{l}\text { Leaves and residues of fruit and } \\
\text { border trees, live fences such as } \\
\text { Vernonia }\end{array}$ & $\begin{array}{l}\text { Leaves and fruits of shade trees, } \\
\text { and weedy herbs in off-seasons }\end{array}$ & $\begin{array}{l}\text { Leaves and fruits of shade } \\
\text { trees, shrubs and weedy herbs } \\
\text { in off-seasons }\end{array}$ & $\begin{array}{l}\text { Crop residues, leaves, and } \\
\text { fruits of parkland and } \\
\text { shade trees }\end{array}$ \\
\hline Medicinal values & $\begin{array}{l}\text { Vegetables, tubers, roots, fruits, } \\
\text { shrubs and herbs in the system, } \\
\text { e.g. 'Qoricha bineensaa'-snake } \\
\text { poison }\end{array}$ & $\begin{array}{l}\text { Croton, Vernonia, Olea, Premna, } \\
\text { Qomanyoo (Brucea } \\
\text { antidysenterica J.F.Mill.), } \\
\text { 'Gizaawwaa', and others }\end{array}$ & $\begin{array}{l}\text { Maesa lanceolata, Croton, } \\
\text { 'Qomanyoo' (Brucea } \\
\text { antidysenterica), Premna, } \\
\text { Hagenia, and other shrubs, } \\
\text { trees and climbers }\end{array}$ & $\begin{array}{l}\text { Vernonia, Maesa lanceolata, } \\
\text { Croton, Qomanyoo (Brucea } \\
\text { antidysenterica), Premna }\end{array}$ \\
\hline \multicolumn{5}{|l|}{ Regulatory Services } \\
\hline Climate regulation & $\begin{array}{l}\text { Shade of fruit trees and others } \\
\text { in the system }\end{array}$ & $\begin{array}{l}\text { Coffee shades and shrubs used } \\
\text { as soil moisture protection, } \\
\text { shade provision for human and } \\
\text { animals }\end{array}$ & $\begin{array}{l}\text { Coffee shades and shrubs } \\
\text { used as soil moisture } \\
\text { protection, shade for lives }\end{array}$ & \\
\hline Erosion protection & $\begin{array}{l}\text { More density more protection, } \\
\text { no tillage }\end{array}$ & $\begin{array}{l}\text { Zero tillage, live fences, and } \\
\text { leafy mulches of shade and } \\
\text { other trees and shrubs }\end{array}$ & $\begin{array}{l}\text { Uncultivable and protected to } \\
\text { some extent }\end{array}$ & $\begin{array}{l}\text { Vetivar grass strips and } \\
\text { conservation structures }\end{array}$ \\
\hline
\end{tabular}


Table 2. Cont

\begin{tabular}{|c|c|c|c|c|}
\hline \multicolumn{5}{|c|}{ Major Farming Systems } \\
\hline Types of Services & Homegarden AF & Plantation Coffee & Semi-Forest Coffee & Crop Production \\
\hline Water purification & & & $\begin{array}{l}\text { Quality streams, and springs } \\
\text { as a result of uncultivability }\end{array}$ & \\
\hline \multicolumn{5}{|l|}{ Cultural Services } \\
\hline Spiritual values & Big trees like Ficus species & $\begin{array}{l}\text { Availability and } \\
\text { multifunctionality of big and } \\
\text { culturally respected trees }\end{array}$ & $\begin{array}{l}\text { Availability and } \\
\text { multifunctionality of big and } \\
\text { culturally respected trees }\end{array}$ & \\
\hline Aesthetic values & Landscape formation & $\begin{array}{l}\text { Uniformity within each Under } \\
\text { and lower storey species }\end{array}$ & Layers of different storey & \\
\hline Educational values & $\begin{array}{l}\text { Fruits, roots and tubers, and } \\
\text { vegetables are becoming areas } \\
\text { of research }\end{array}$ & $\begin{array}{l}\text { Area of interest for international } \\
\text { research on organic coffee } \\
\text { production and multiplication } \\
\text { systems }\end{array}$ & $\begin{array}{l}\text { Area of interest for } \\
\text { international research on } \\
\text { organic coffee production and } \\
\text { management systems }\end{array}$ & $\begin{array}{l}\text { Research interest to } \\
\text { enhance production and } \\
\text { productivity }\end{array}$ \\
\hline Recreation/ecotourism & $\begin{array}{l}\text { Opportunities of evergreenness } \\
\text { and attractiveness }\end{array}$ & $\begin{array}{l}\text { Area of interest to maintain and } \\
\text { enjoy cultural and natural } \\
\text { landscapes }\end{array}$ & $\begin{array}{l}\text { Area of interest to enjoy the } \\
\text { biodiversity, cultural, and } \\
\text { natural landscapes }\end{array}$ & \\
\hline \multicolumn{5}{|l|}{ Supporting Services } \\
\hline Soil formation & $\begin{array}{l}\text { Litter falls, leguminous shrubs } \\
\text { and crops, erosion control and } \\
\text { livestock dung }\end{array}$ & $\begin{array}{l}\text { Litter falls, erosion control of } \\
\text { shade trees/shrubs }\end{array}$ & $\begin{array}{l}\text { Litter falls, erosion control, } \\
\text { and no tillage }\end{array}$ & $\begin{array}{l}\text { Retention of crop residues } \\
\text { through conservation } \\
\text { agriculture }\end{array}$ \\
\hline Habitat provision & $\begin{array}{l}\text { Birds, insects, wild animals and } \\
\text { others used the system, and the } \\
\text { opportunity for corridors and } \\
\text { nearby patches }\end{array}$ & $\begin{array}{l}\text { Birds, insects, wild animals } \\
\text { (climbers), and others used the } \\
\text { system as home }\end{array}$ & $\begin{array}{l}\text { Home for most types of living } \\
\text { organisms, including big } \\
\text { mammals, reptiles, etc. }\end{array}$ & $\begin{array}{l}\text { Soil and water } \\
\text { conservation structures for } \\
\text { small animals and insects }\end{array}$ \\
\hline
\end{tabular}

From the above table, 15 actual and potential ecosystem services were mapped, and grouped into provision, supporting, regulating, and cultural ecosystem service categories. This has been done by focus group discussions and key informant interviews. 
Table 3. Dynamics and temporal trends of ecosystem services of the major farming systems in the Yayo BR.

\begin{tabular}{|c|c|c|c|c|c|c|c|c|c|c|c|c|}
\hline \multirow{3}{*}{ Ecosystem Services } & \multicolumn{12}{|c|}{ Relative Importance of Ecosystem Services for Major Farming System in (\%) } \\
\hline & \multicolumn{3}{|c|}{ Homegarden AF System } & \multicolumn{3}{|c|}{ Plantation Coffee System } & \multicolumn{3}{|c|}{ Semi-Forest Coffee System } & \multicolumn{3}{|c|}{ Annual Crop Land } \\
\hline & 1987-1996 & 1997-2006 & 2007-2016 & 1987-1996 & 1997-2006 & $2007-2016$ & 1987-1996 & 1997-2006 & $2007-2016$ & 1987-1996 & 1997-2006 & 2007-2016 \\
\hline Food Provision & 85.8 & 70.9 & 55.8 & 55 & 76.6 & 78.3 & 96.6 & 78.3 & 70 & 98.3 & 100 & 100 \\
\hline $\mathrm{BD} /$ Genetic resources & 76.6 & 55 & 27.5 & 78.3 & 70.9 & 42.5 & 97.5 & 87.5 & 99.1 & 29.2 & 15 & 6.7 \\
\hline Water Resource Provision & 9.9 & 0 & 5.8 & 5.8 & 2.5 & 1.6 & 85.8 & 88.4 & 91.6 & 0 & 7.5 & 0 \\
\hline Fuelwood and Timber & 56.6 & 76.6 & 85.8 & 92.5 & 100 & 100 & 100 & 100 & 96.6 & 67.5 & 98.4 & 98.4 \\
\hline Fodder Provision & 37.5 & 67.4 & 87.5 & 95 & 97.5 & 91.7 & 100 & 100 & 91.7 & 52.5 & 63.3 & 64.2 \\
\hline Medicinal Value & 79.1 & 93.3 & 100 & 99.2 & 100 & 100 & 100 & 100 & 92.4 & 73.4 & 87.5 & 84.2 \\
\hline Climate Regulation & 93.4 & 100 & 100 & 95.9 & 100 & 100 & 100 & 100 & 100 & 32.5 & 43.3 & 24.2 \\
\hline Erosion Protection & 97.1 & 100 & 99.1 & 95.8 & 100 & 97.5 & 100 & 100 & 100 & 48.3 & 36.7 & 38.3 \\
\hline Water Purification & 0 & 4.2 & 7.5 & 6.7 & 0 & 0 & 60 & 58.4 & 39.2 & 5 & 0 & 0 \\
\hline Spiritual Services & 59.1 & 33.4 & 30 & 33.4 & 8.3 & 4.2 & 83.4 & 79.1 & 68.4 & 10 & 3.3 & 3.3 \\
\hline Aesthetic Information & 65.9 & 92.5 & 96.7 & 84.2 & 96.7 & 87.5 & 100 & 96.7 & 100 & 3.3 & 2.5 & 15 \\
\hline Educational Services & 78.3 & 95 & 96.7 & 94.2 & 96.7 & 100 & 100 & 96.6 & 100 & 40 & 60 & 50.8 \\
\hline Recreation and Ecotourism & 81.7 & 85.8 & 97.5 & 85.8 & 77.5 & 100 & 93.4 & 96.7 & 95.8 & 0 & 3.3 & 1.7 \\
\hline Soil Formation & 95.1 & 100 & 100 & 94.2 & 94.2 & 100 & 100 & 100 & 100 & 36.7 & 14.1 & 7.5 \\
\hline Habitat Provision & 91.6 & 100 & 100 & 99.2 & 100 & 100 & 98.3 & 100 & 100 & 31.7 & 56.7 & 52.5 \\
\hline
\end{tabular}

The result illustrated the description results of ecosystem services being provided by the four major farming systems in the Yayo BR. 
Table 4. Summary of trends and tradeoffs of ecosystem services in the major farming systems in the Yayo BR.

\begin{tabular}{|c|c|c|c|c|c|c|c|c|c|c|c|c|c|c|c|}
\hline \multirow[b]{2}{*}{$\begin{array}{l}\text { Major Farming } \\
\text { Systems }\end{array}$} & \multicolumn{15}{|c|}{ Temporal Trends of Ecosystem Services within the Intervals of (1987-1996, 1997-2006 and 2007-2016) } \\
\hline & 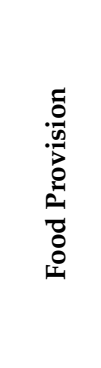 & 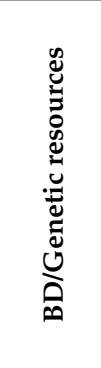 & 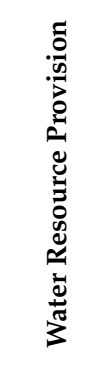 & 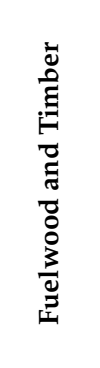 & 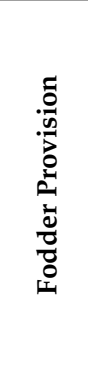 & 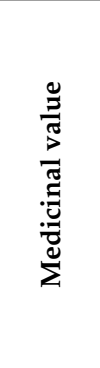 & 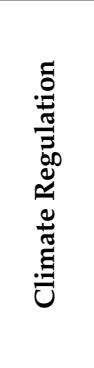 & 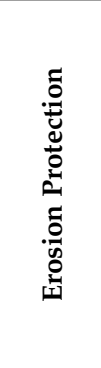 & 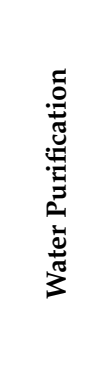 & 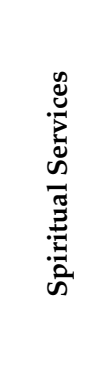 & 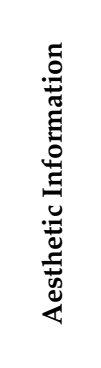 & 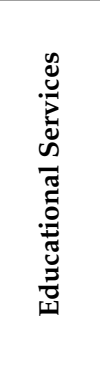 & 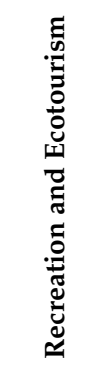 & 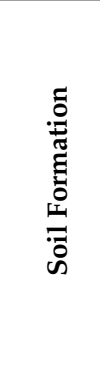 & 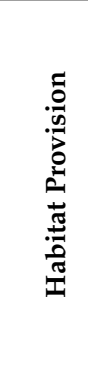 \\
\hline Homegarden & +-- & +-- & +-+ & +++ & +++ & +++ & +++ & ++- & +++ & +-- & +++ & +++ & +++ & +++ & +++ \\
\hline Plantation Coffee & +++ & +-- & +-- & +++ & ++- & +++ & +++ & ++- & +-- & +-- & ++- & +++ & +-+ & +++ & +++ \\
\hline Semi-Forest Coffee & +-- & +-+ & +++ & +-+ & ++- & ++- & +++ & +++ & +-- & +-- & +-+ & +-+ & +++ & +++ & ++ \\
\hline Annual Crop & +++ & +-- & ++- & +++ & +++ & ++- & ++- & +-+ & +-- & +-- & +-+ & ++- & ++- & +-- & ++- \\
\hline
\end{tabular}

Annual Crop

Note: " ++ +" is to indicate that the services have been increasing since 1987; "+ - " is to indicate that the services have been decreasing since 1987; " ++- " is to indicate that the services

increased from 1997 to 2006, and then decreasing from 2007 to 2016; “+ - +" is to indicate that the services decreased from 1997 to 2006 , and then increased from 2007 to 2016. 


\subsection{Links of Agro-Biodiversity and Ecosystem Services in the Major Farming Systems}

The result of this study revealed that the diversity of trees and shrubs in the major farming systems contributes to the provisioning of wood and non-wood products, and protects the environment, thereby enhancing ecosystem services of the systems (Table 2). The major farming systems, which were identified in the current study, have shown differences not only in the diversity, density, and composition of trees, but also in the ecosystem services they have been providing (Tables 3 and 4). In line with the findings of [28], the decrease in the diversity of trees and perennial components of the system, and its gradual replacement with new cash and annual food crops, could jeopardize the integrity and complexity of the system. This decreasing of diversity has been markedly modifying the functional properties of ecosystems [25], and the services they provide. Results of this study also showed that agro-biodiversity and ecosystem services being provided by those major farming systems are positively interrelated. On the other hand, most of the ecosystem services are derived mainly from annual crops systems, with the lowest species diversity and evenness, are declining rapidly. However, in the same system, this trend is reversed in some cases, like food, forage, and fuelwood provisions, where they have been increased in contrast to the diversity indices.

From the above table, we can estimate the relationships of diversity indices in each farming system and its different ecosystem services. The perception of the respondents for provision of the majority of ecosystem services was higher in areas of high taxon diversity, indicating both positive relationships and slight tradeoffs in maximizing single ecosystem services [29]. For example, SFC and HG systems, which have higher diversity indices, showed higher relative importance in pure water, fuelwood, timber, climate regulation, aesthetic, educational, recreational, soil formation, and habitat provisions.

Finally, the relationship between biodiversity and the rapidly expanding research and policy field of ecosystem services is confusing according to [30], globally in general, and in the Yayo Coffee Biosphere Reserve in particular. This statement underlines that the ecosystem science and human practices have not yet absorbed the lessons of this complex relationship, which suggests an urgent need to develop the interdisciplinary science of ecosystem management, bringing together ecologists, conservation biologists, resource economists, and others.

\section{Conclusions and Recommendations}

The major farming systems identified in this study, for the biodiversity comparison among them and ecosystem services (ES) assessment, are very common in the area, and they are of substantial social, economic, ecological, and environmental importance. The species compositions, management actions, and changes in the farming agro-ecosystems could affect the BR management towards sustainable development negatively and/or positively. Most of the temporal trends in the ES of the major farming systems have been increasing, especially in the more diversified systems, such as homegardens and semi-forest coffee systems. Regarding contemporary annual crop production system with lowest species diversity, most of them have shown declining trends. Food provisioning from annual crop farming system is highly significant, but many other ecosystem services, particularly those with regulatory, cultural, and supporting services, have been declined.

Ecosystems and the services they provide are critically important to our wellbeing and economic prosperity. This general truth underlines that people and their environment are inseparable. However, humans have been modifying the natural landscape and ecosystem functions to intensify certain provisioning services, such as food supply at the expense of others, for example, regulating services regardless of their sustainability. If local communities find themselves on the losing end of conservation measures, they will tend to overharvest the available resources to satisfy their basic needs.

Author Contributions: M.S.D. conducted the field work and wrote the manuscript. D.H.F. and L.B.-F. have supported and enhanced the quality and structure of the study and contributed ample of technical, logical and structural supports from the beginning.

Funding: This research was funded by Oromia Agricultural Research Institute (31000 Ethiopian Birr), the NutriHAF Africa project from the German Federal Ministry of Food and Agriculture (BMEL) (1000 Euro), 
and Jimma University (10000 Ethiopian Birr). The publishing cost is covered by the NutriHAF Africa project from the German Federal Ministry of Food and Agriculture (BMEL).

Acknowledgments: My acknowledgement also goes for all Bako Agricultural Research Center (BARC) staffs, especially to Teshome Bogale (Center manager), to Effa Wolteji, and to all Agroforestry research team workers of BARC. My great thanks are also owed to all JUCAVM staff members, particularly to Gudina Legesse and Zerihun Kibebew, to Yayo and Hurumu districts' agricultural experts, ECFF experts and Das: particularly to Derartu Mitiku, to Gemechu, to Tadelech, to Diriba, to Gedefa, and to Matiwos.

Conflicts of Interest: The authors declare no conflict of interest. The funders had no role in the design of the study; in the collection, analyses, or interpretation of data; in the writing of the manuscript, and in the decision to publish the results.

\section{Appendix A Data Collection Formats/Sheets}

\section{Structured Questionnaires for Respondents}

General information of the respondents

Field enumerator Date

Respondent's Name

District Name of the PA Gender: A. Female B. Male

GPS coordinates of residence (coordinates): North: East: Altitude (m.a.s.l.):

Dynamics and temporal changes in ecosystem services major farming systems in the Biosphere Reserve

Table A1. Which of the following land-use/land-cover types do you practice or own and which are the associated benefits you utilized from each farming system type and each time period. Please indicate the importance through the numbers 1 = very important, $2=$ important, $3=$ medium, $4=\operatorname{do}$ not know, $0=$ not important.

\begin{tabular}{|c|c|c|c|c|c|c|c|c|c|c|c|c|c|c|c|}
\hline \multirow{4}{*}{ ٍँّ } & \multirow{4}{*}{ 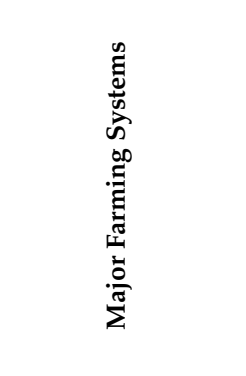 } & \multicolumn{14}{|c|}{ Types of Ecosystem Services } \\
\hline & & \multicolumn{6}{|c|}{ Provision Services } & \multicolumn{3}{|c|}{ Regulation } & \multicolumn{4}{|c|}{ Cultural } & Supporting \\
\hline & & \multicolumn{6}{|c|}{$\begin{array}{l}\text { 1, Food production } \\
\text { 2, Biodiversity/Genetic resources } \\
\text { 3, Water (drinking, } \\
\text { cooking, Irrigation) } \\
\text { 4, Fuelwood and Timber } \\
\text { 5, Fodder } \\
\text { 6, Natural medicines }\end{array}$} & \multicolumn{3}{|c|}{$\begin{array}{l}1, \text { Climate } \\
\text { regulation } \\
2, \text { Erosion } \\
\text { protection } \\
\text { 3, Water } \\
\text { purification }\end{array}$} & \multicolumn{4}{|c|}{$\begin{array}{l}\text { 1, Spiritual values } \\
\text { 2, Aesthetic values } \\
\text { 3, Educational values } \\
\text { 4, Recreation and } \\
\text { Ecotourism values }\end{array}$} & $\begin{array}{l}\text { 1, Soil } \\
\text { formation } \\
2, \text { Habitat } \\
\text { provision }\end{array}$ \\
\hline & & A & B & $\mathrm{C}$ & D & $\mathrm{E}$ & F & G & $\mathbf{H}$ & I & $\mathbf{J}$ & K & L & $\mathbf{M}$ & $\mathbf{N}$ \\
\hline \multirow{4}{*}{ 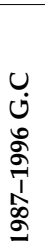 } & Homegarden AF & & & & & & & & & & & & & & \\
\hline & Plantation Coffee & & & & & & & & & & & & & & \\
\hline & $\begin{array}{l}\text { Semi-Forest Coffee } \\
\text { Systems (SFCS) }\end{array}$ & & & & & & & & & & & & & & \\
\hline & Annual Croplands & & & & & & & & & & & & & & \\
\hline
\end{tabular}


Table A1. Cont.

\begin{tabular}{|c|c|c|c|c|c|c|c|c|c|c|c|c|c|c|}
\hline \multirow{4}{*}{ હँّ } & \multirow{4}{*}{ 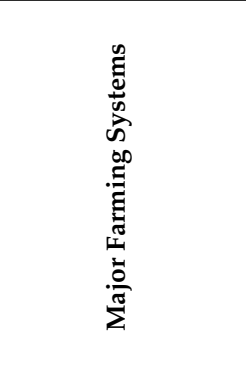 } & \multicolumn{13}{|c|}{ Types of Ecosystem Services } \\
\hline & & \multirow{2}{*}{\multicolumn{6}{|c|}{\begin{tabular}{l}
\multicolumn{1}{c}{ Provision services } \\
1, Food production \\
2, Biodiversity/Genetic resources \\
3, Water (drinking, \\
cooking, Irrigation) \\
4, Fuelwood and Timber \\
5, Fodder \\
6, Natural medicines
\end{tabular}}} & \multirow{2}{*}{\multicolumn{3}{|c|}{$\begin{array}{l}\quad \text { Regulation } \\
\text { 1, Climate } \\
\text { regulation } \\
\text { 2, Erosion } \\
\text { protection } \\
\text { 3, Water } \\
\text { purification }\end{array}$}} & \multicolumn{3}{|c|}{ Cultural } & Supporting \\
\hline & & & & & & & & & & & \multicolumn{3}{|c|}{$\begin{array}{l}\text { 1, Spiritual values } \\
\text { 2, Aesthetic values } \\
\text { 3, Educational values } \\
\text { 4, Recreation and } \\
\text { Ecotourism values }\end{array}$} & $\begin{array}{l}\text { 1, Soil } \\
\text { formation } \\
2, \text { Habitat } \\
\text { provision }\end{array}$ \\
\hline & & A & B & C & D & $\mathrm{E}$ & F & G & H & I & $\mathbf{J}$ & $\mathbf{K}$ & $\mathbf{M}$ & $\mathbf{O}$ \\
\hline \multirow{4}{*}{ 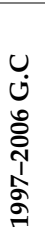 } & Homegarden AF & & & & & & & & & & & & & \\
\hline & Plantation Coffee & & & & & & & & & & & & & \\
\hline & $\begin{array}{l}\text { Semi-Forest Coffee } \\
\text { Systems (SFCS) }\end{array}$ & & & & & & & & & & & & & \\
\hline & Annual Croplands & & & & & & & & & & & & & \\
\hline \multirow{4}{*}{ ઇ્ల } & & \multicolumn{13}{|c|}{ Types of Ecosystem Services } \\
\hline & $\mathfrak{g}^{\infty}$ & \multicolumn{6}{|c|}{ Provision services } & \multicolumn{3}{|c|}{ Regulation } & \multicolumn{3}{|c|}{ Cultural } & $\overline{\text { Supporting }}$ \\
\hline & 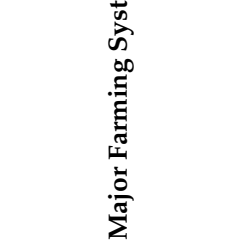 & \multicolumn{6}{|c|}{$\begin{array}{l}\text { 1, Food production } \\
\text { 2, Biodiversity/Genetic resources } \\
\text { 3, Water (drinking, } \\
\text { cooking, Irrigation) } \\
\text { 4, Fuelwood and Timber } \\
\text { 5, Fodder } \\
\text { 6, Natural medicines }\end{array}$} & \multicolumn{3}{|c|}{$\begin{array}{l}1, \text { Climate } \\
\text { regulation } \\
2, \text { Erosion } \\
\text { protection } \\
3 \text {, Water } \\
\text { purification }\end{array}$} & \multicolumn{3}{|c|}{$\begin{array}{l}\text { 1, Spiritual values } \\
\text { 2, Aesthetic values } \\
\text { 3, Educational values } \\
\text { 4, Recreation and } \\
\text { Ecotourism values }\end{array}$} & $\begin{array}{l}\text { 1, Soil } \\
\text { formation } \\
2, \text { Habitat } \\
\text { provision }\end{array}$ \\
\hline & & A & B & $\mathrm{C}$ & $\mathbf{D}$ & $\mathrm{E}$ & F & G & $\mathbf{H}$ & I & $\mathbf{J}$ & K & $\mathbf{M}$ & O \\
\hline \multirow{4}{*}{ 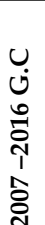 } & Homegarden AF & & & & & & & & & & & & & \\
\hline & Plantation Coffee & & & & & & & & & & & & & \\
\hline & $\begin{array}{l}\text { Semi-Forest Coffee } \\
\text { Systems (SFCS) }\end{array}$ & & & & & & & & & & & & & \\
\hline & Annual Croplands & & & & & & & & & & & & & \\
\hline
\end{tabular}

If you do have any additional information and or remark it is free and open to add. Additional information that should be specified 
Table A2. Species Compositions of Homegarden System.

\begin{tabular}{|c|c|c|c|c|c|c|}
\hline S. Number. & $\begin{array}{l}\text { Local Name/s of the } \\
\text { Plant/Crop Species }\end{array}$ & Scientific Name & Family Name & $\begin{array}{l}\text { Plant/Crop Typology } \\
\text { 1. Fruit trees } \\
\text { 2. Timber trees } \\
\text { 3. Forage } \\
\text { 4. Shade trees } \\
\text { 5. Root and tuber } \\
\text { 6. Vegetables } \\
\text { 7. Pulse } \\
\text { 8. Cereals } \\
\text { 9. Others, specify }\end{array}$ & $\begin{array}{l}\text { Purpose of the } \\
\text { Plants/Crops in the } \\
\text { System: } \\
\text { 1. Food } \\
\text { 2. Medicine } \\
\text { 3. Fuelwood } \\
\text { 4. Construction } \\
\text { 5. Fodder } \\
\text { 6. Soil conservation } \\
\text { 7. Income generation } \\
\text { 8. Others: } \\
\text { 9. Shade }\end{array}$ & $\begin{array}{l}\text { Abundance of the } \\
\text { species in the system }\end{array}$ \\
\hline 1 & Abiraangoo & & & 6. Vegetables & 1 and 2 & 13 \\
\hline 2 & Ancootee & Coccinia abyssinica & Cucurbitaceae & 5. Root and tuber & 1 and 7 & 49 \\
\hline 3 & Avokaadoo & Persea americana & Lauraceae & 1. Fruit trees & 1 and 7 & 22 \\
\hline 4 & Baargamoo & $\begin{array}{l}\text { Eucalyptus } \\
\text { camaldulensis }\end{array}$ & Myrtaceae & 2. Timber trees & 3 and 4 & 57 \\
\hline 5 & Baqarii/Kefii & Salvia nilotica & Lamiaceae & 9. Spice & 8. spice & 12 \\
\hline 6 & Barbaree & Capsicum annuum & Solanaceae & 9. Spice & 1,7 , and 8 & 30 \\
\hline 7 & Bassoobilaa & Ocimum americanum & Lamiaceae & 9. Spice & 8. spice & 11 \\
\hline 8 & Boqqolloo & Zea mays & Poaceae & 8. Cereals & 1. Food & 221 \\
\hline 9 & Buna & Coffea arabica & Rubiaceae & 9. Cash crop & 1 and 7 & 219 \\
\hline 10 & Burtukaana & Citrus sinensis & Rutaceae & 1. Fruit trees & 1 and 7 & 7 \\
\hline 11 & Caatii & Catha edulis & Celastraceae & 9. Cash crop & 7. Income generation & 218 \\
\hline 12 & Cadaa & Euphorbia tirucalli & Euphorbiaceae & 9. Shrub & 8. live fence & 64 \\
\hline 13 & Dabaaqula/Buqqee & Cucurbita pepo & Cucurbitaceae & 6. Vegetables & 1. Food & 16 \\
\hline 14 & Dafee/Boloqqee & Phaseolus vulgaris & Fabaceae & 7. Pulse & 1. Food & 410 \\
\hline 15 & Dinnicha Oromoo & Plectranthus edulis & Lamiaceae & 5. Root and tuber & 1. Food & 5 \\
\hline 16 & Eebicha & $\begin{array}{c}\text { Vernonia } \\
\text { amygdalina/schimperi }\end{array}$ & Asteraceae & 3. Forage & $2,3,5$, and 6 & 45 \\
\hline 17 & Geeshoo & Rhamnus prinoides & Rhamnaceae & 9. Shrub & 1 and 7 & 6 \\
\hline 18 & Goodarree & Colocasia esculenta & Araceae & 5. Root and tuber & 1. Food & 50 \\
\hline 19 & Giraaviiliyaa & Grevillea robusta & Proteaceae & 2. Timber trees & 3 and 4 & 24 \\
\hline 20 & Harangamaa & Maerua aethiopica & Capparidaceae & 9. Climber & 8. Live fence & 16 \\
\hline 21 & Hundee diimaa & Beta vulgaris & Chenopodiaceae & 5. Root and tuber & 1 and 7 & 20 \\
\hline 22 & Indoodee & Phytolacca dodecandra & Phytolaccaceae & 9. Climber & 2 and 6 & 3 \\
\hline 23 & Irdii & Curcuma domestica & Zingiberaceae & 9. Spice & 8. Spice & 20 \\
\hline 24 & Kaarotii & Daucus carota & Apiaceae & 5. Root and tuber & 1 and 7 & 8 \\
\hline
\end{tabular}


Table A2. Cont.

\begin{tabular}{|c|c|c|c|c|c|c|}
\hline S. Number. & $\begin{array}{l}\text { Local Name/s of the } \\
\text { Plant/Crop Species }\end{array}$ & Scientific Name & Family Name & $\begin{array}{l}\text { Plant/Crop Typology } \\
\text { 1. Fruit trees } \\
\text { 2. Timber trees } \\
\text { 3. Forage } \\
\text { 4. Shade trees } \\
\text { 5. Root and tuber } \\
\text { 6. Vegetables } \\
\text { 7. Pulse } \\
\text { 8. Cereals } \\
\text { 9. Others, specify }\end{array}$ & $\begin{array}{l}\text { Purpose of the } \\
\text { Plants/Crops in the } \\
\text { System: } \\
\text { 1. Food } \\
\text { 2. Medicine } \\
\text { 3. Fuelwood } \\
\text { 4. Construction } \\
\text { 5. Fodder } \\
\text { 6. Soil conservation } \\
\text { 7. Income generation } \\
\text { 8. Others: } \\
\text { 9. Shade }\end{array}$ & $\begin{array}{l}\text { Abundance of the } \\
\text { species in the system }\end{array}$ \\
\hline 25 & Kaashimiirii & Conyza stricta & Asteraceae & 1. Fruit trees & 1 and 7 & 9 \\
\hline 26 & Kookii & Prunus persica & Rosacaea & 1. Fruit trees & 1 and 7 & 10 \\
\hline 27 & Korchii & Erythrina abyssinica & Fabaceae & 9. Shrub & 2,3 , and 4 & 6 \\
\hline 28 & Loomii & Citrus aurantifolia & Rutaceae & 1. Fruit trees & 1,2 , and 7 & 6 \\
\hline 29 & Maangoo & Mangifera indica & Anacardiaceae & 1. Fruit trees & 1 and 7 & 29 \\
\hline 30 & Marga Veetiivaar & & & 9. Grass & 6. Soil conservation & 31 \\
\hline 31 & Mishingaa & Sorghum bicolor & Poaceae & 8. Cereals & 1. Food & 38 \\
\hline 32 & Mixaaxisa & Ipomoea batatas & Convolvulaceae & 5. Root and tuber & 1 and 7 & 19 \\
\hline 33 & Muuzii & Musa acuminata & Musaceae & 1. Fruit trees & 1 and 7 & 56 \\
\hline 34 & Paappayyaa & Carica papaya & Caricaceae & 1. Fruit trees & 1 and 7 & 11 \\
\hline 35 & Qobboo & Ricinus communis & Euphorbiaceae & 7. Pulse & 3 and 7 & 15 \\
\hline 36 & Qoccinee & & & 9. Climber & 1. Food & 3 \\
\hline 37 & Qoccoo/Enset & Ensete ventricosum & Musaceae & 5. Root and tuber & 1. Food & 197 \\
\hline 38 & Qoricha bofaa & & & 9. Shrub & 2. Medicine & 6 \\
\hline 39 & Qullubbii & Allium sativum & Alliaceae & 9. Spice & 2,7 , and 8 . Spice & 31 \\
\hline 40 & Raafuu Habashaa & Brassica carinata & Brassicaceae & 6. Vegetables & 1. Food & 151 \\
\hline 41 & Raafuu Maraa & Brassica oleracea & Brassicaceae & 6. Vegetables & 1 and 7 & 56 \\
\hline 42 & Rigaa arbaa & Bridelia micrantha & Euphorbiaceae & 9. Shrub & 3. Fuelwood & 4 \\
\hline 43 & Sasbaaniyaa & Sesbania sesban & Fabaceae & 9. Shrub & 3 and 6 & 32 \\
\hline 44 & Shonkoora Agadaa & Saccharum officinarum & Poaceae & 9. Industrial crop & 1 and 7 & 146 \\
\hline 45 & Shunkurtii & Allium cepa & Alliaceae & 9. Spice & 1 and 7 & 16 \\
\hline 46 & Turungoo & Citrus medica & Rutaceae & 1. Fruit trees & 1 and 7 & 3 \\
\hline 47 & Waddeessa & Cordia africana & Boraginaceae & 2. Timber trees & 3,4, and 7 & 8 \\
\hline 48 & Xeenaaddaam & Ruta chalepensis & Rutaceae & 9. Spice & 2. Medicine & 14 \\
\hline 49 & Zayituunaa & Psidium guajava & Myrtaceae & 1. Fruit trees & 1. Food & 5 \\
\hline 50 & Zinjibila & Zingiber officinale & Zingiberaceae & 9. Spice & 2,7 , and 8 . Spice & 72 \\
\hline
\end{tabular}


Table A3. Species Compositions of Plantation Coffee System.

\begin{tabular}{|c|c|c|c|c|c|c|}
\hline S. Number & $\begin{array}{l}\text { Local Name/s of the } \\
\text { Plant/Crop Species }\end{array}$ & Scientific Name & Family Name & $\begin{array}{l}\text { Plant/Crop Typology } \\
\text { 1. Fruit trees } \\
\text { 2. Timber trees } \\
\text { 3. Forage } \\
\text { 4. Shade trees } \\
\text { 5. Root and tuber } \\
\text { 6. Vegetables } \\
\text { 7. Pulse } \\
\text { 8. Cereals } \\
\text { 9. Others, specify }\end{array}$ & $\begin{array}{l}\text { Purpose of the } \\
\text { Plants/Crops in the } \\
\text { System: } \\
\text { 1. Food } \\
\text { 2. Medicine } \\
\text { 3. Fuelwood } \\
\text { 4. Construction } \\
\text { 5. Fodder } \\
\text { 6. Soil conservation } \\
\text { 7. Income generation } \\
\text { 8. Others } \\
\text { 9. Shade }\end{array}$ & $\begin{array}{l}\text { Abundance of the } \\
\text { species in the system }\end{array}$ \\
\hline 1 & Abbayyii & Maesa lanceolata & Myrsinaceae & 4. Shade trees & $2,3,5$, and 6 & 7 \\
\hline 2 & Baargamoo Diimaa & $\begin{array}{l}\text { Eucalyptus } \\
\text { camaldulensis }\end{array}$ & Myrtaceae & 2. Timber trees & 3,4, and 7 & 9 \\
\hline 3 & Bakkanniisa & Croton macrostachyus & Euphorbiaceae & 4. Shade trees & 2,6 , and 9 & 13 \\
\hline 4 & Buna & Coffea arabica & Rubiaceae & 9. Cash crop & 1 and 7 & 965 \\
\hline 5 & Ceekaa & Calpurnia aurea & Fabaceae & 9. Shrub & 3. Fuelwood & 9 \\
\hline 6 & Dambii & Ficus thonningii & Moraceae & 4. Shade trees & $3,4,5$, and 6 & 3 \\
\hline 7 & Dhummuugaa & Justicia schimperiana & Acanthaceae & 9. Shrub & $2,3,4$, and 6 & 6 \\
\hline 8 & Eebicha & Vernonia amygdalina & Asteraceae & 3. Forage & $2,3,5$, and 6 & 20 \\
\hline 9 & Gatamaa/Gagamaa & Olea welwitschii & Oleaceae & 2. Timber trees & $2,3,4$, and 9 & 1 \\
\hline 10 & Geeshoo & Rhamnus prinoides & Rhamnaceae & 9. Shrub & 1 and 7 & 5 \\
\hline 11 & Gizaawwaa & Withania somnifera & Solanaceae & 9. Shrub & 2 and 3 & 14 \\
\hline 12 & $\begin{array}{c}\text { Giraaviiliiyaa/Muka } \\
\text { qawwee }\end{array}$ & Grevillea robusta & Proteaceae & 2. Timber trees & $2,3,4,7$, and 9 & 4 \\
\hline 13 & Harbuu & Ficus sur & Moraceae & 4. Shade trees & 1,3 , and 5 & 3 \\
\hline 14 & Hoomii & Prunus africana & Rosaceae & 2. Timber trees & $2,3,4$, and 7 & 2 \\
\hline 15 & Indoodee & Phytolacca dodecandra & Phytolaccaceae & 9. Climber & 2 and 8 , purification & 2 \\
\hline 16 & Laaftoo & Acacia sieberiana & Fabaceae & 4. Shade trees & $3,4,5,6$, and 9 & 15 \\
\hline 17 & Mukarbaa/Ambabbeessa & a Albizia gummifera & Fabaceae & 4. Shade trees & 9. Shade & 12 \\
\hline 18 & oogiwoo/koroolimaa & Ethiopian candimon & & 9. Spice & 7 and 8. Spice & 41 \\
\hline 19 & Oobdaa & Ficus vasta & Moraceae & 4. Shade trees & $3,5,6$, and 9 & 5 \\
\hline 20 & Qararoo & Acokanthera schimperi & Apocynaceae & 2. Timber trees & 3 and 4 & 9 \\
\hline 21 & Qolaadii & Mimusops kummel & Sapotaceae & 4. Shade trees & 3,4 , and 9 & 4 \\
\hline 22 & Qomanyoo & Brucea antidysenterica & Simaroubaceae & 9. Shrub & 2 and 3 & 1 \\
\hline 23 & Reejjii & Vernonia rueppellii & Asteraceae & 4 and 9. Shrub & 3,6 , and 9 & 36 \\
\hline 24 & Sesbania & Sesbania sesban & Fabaceae & 9. Shrub & $3,4,5,6$, and 9 & 42 \\
\hline
\end{tabular}


Table A3. Cont.

\begin{tabular}{|c|c|c|c|c|c|c|}
\hline S. Number & $\begin{array}{l}\text { Local Name/s of the } \\
\text { Plant/Crop Species }\end{array}$ & Scientific Name & Family Name & $\begin{array}{l}\text { Plant/Crop Typology } \\
\text { 1. Fruit trees } \\
\text { 2. Timber trees } \\
\text { 3. Forage } \\
\text { 4. Shade trees } \\
\text { 5. Root and tuber } \\
\text { 6. Vegetables } \\
\text { 7. Pulse } \\
\text { 8. Cereals } \\
\text { 9. Others, specify }\end{array}$ & $\begin{array}{l}\text { Purpose of the } \\
\text { Plants/Crops in the } \\
\text { System: } \\
\text { 1. Food } \\
\text { 2. Medicine } \\
\text { 3. Fuelwood } \\
\text { 4. Construction } \\
\text { 5. Fodder } \\
\text { 6. Soil conservation } \\
\text { 7. Income generation } \\
\text { 8. Others } \\
\text { 9. Shade }\end{array}$ & $\begin{array}{l}\text { Abundance of the } \\
\text { species in the system }\end{array}$ \\
\hline 25 & Sondii & Acacia lahai & Fabaceae & 4. Shade trees & $3,4,5,6$, and 9 & 5 \\
\hline 26 & Sootalloo & Millettia ferruginea & Fabaceae & 4. Shade trees & 2,3 , and 6 & 6 \\
\hline 27 & Ulaagaa & Ehretia cymosa & Boraginaceae & 4. Shade trees & 2,3, and 4 & 6 \\
\hline 28 & Waddeessa & Cordia africana & Boraginaceae & 2 and 4 & $3,4,5,7$, and 9 & 12 \\
\hline
\end{tabular}

Table A4. Species Compositions of Semi-Forest Coffee Production System.

\begin{tabular}{|c|c|c|c|c|c|c|}
\hline S. Number & $\begin{array}{l}\text { Local Name/s of the } \\
\text { Plant/Crop Species }\end{array}$ & Scientific Name & Family Name & $\begin{array}{l}\text { Plant/Crop Typology } \\
\text { 1. Fruit trees } \\
\text { 2. Timber trees } \\
\text { 3. Forage } \\
\text { 4. Shade trees } \\
\text { 5. Root and tuber } \\
\text { 6. Vegetables } \\
\text { 7. Pulse } \\
\text { 8. Cereals } \\
\text { 9. Others, specify }\end{array}$ & $\begin{array}{l}\text { Purpose of the } \\
\text { Plants/Crops in the } \\
\text { System: } \\
\text { 1. Food } \\
\text { 2. Medicine } \\
\text { 3. Fuelwood } \\
\text { 4. Construction } \\
\text { 5. Fodder } \\
\text { 6. Soil conservation } \\
\text { 7. Income generation } \\
\text { 8. Others } \\
\text { 9. Shade }\end{array}$ & $\begin{array}{l}\text { Abundance of the } \\
\text { species in the system }\end{array}$ \\
\hline 1 & Abbayyii & Maesa lanceolata & Myrsinaceae & 4. Shade trees & $2,3,5$, and 6 & 5 \\
\hline 2 & Agamsa & Carissa spinarum & Apocynaceae & 9. Shrub, climber & 1,3, and 5 & 13 \\
\hline 3 & Akuukkuu & Oncoba spinosa & Flacourtiaceae & 4. Shade trees & 3. Fuelwood & 10 \\
\hline 4 & Alalee & Albizia grandibracteata & Fabaceae & 4. Shade trees & 3,4, and 6 & 5 \\
\hline 5 & Alaltuu & Salix subserrata & Salicaceae & 9. Shrub & 3 and 4 & 8 \\
\hline 6 & Ambabbeessa/mukarbaa & Albizia gummifera & Fabaceae & 4. Shade trees & 9. Shade & 13 \\
\hline
\end{tabular}


Table A4. Cont.

\begin{tabular}{|c|c|c|c|c|c|c|}
\hline S. Number & $\begin{array}{l}\text { Local Name/s of the } \\
\text { Plant/Crop Species }\end{array}$ & Scientific Name & Family Name & $\begin{array}{l}\text { Plant/Crop Typology } \\
\text { 1. Fruit trees } \\
\text { 2. Timber trees } \\
\text { 3. Forage } \\
\text { 4. Shade trees } \\
\text { 5. Root and tuber } \\
\text { 6. Vegetables } \\
\text { 7. Pulse } \\
\text { 8. Cereals } \\
\text { 9. Others, specify }\end{array}$ & $\begin{array}{l}\text { Purpose of the } \\
\text { Plants/Crops in the } \\
\text { System: } \\
\text { 1. Food } \\
\text { 2. Medicine } \\
\text { 3. Fuelwood } \\
\text { 4. Construction } \\
\text { 5. Fodder } \\
\text { 6. Soil conservation } \\
\text { 7. Income generation } \\
\text { 8. Others } \\
\text { 9. Shade }\end{array}$ & $\begin{array}{l}\text { Abundance of the } \\
\text { species in the system }\end{array}$ \\
\hline 7 & Ambaltaa & Entada abyssinica & Fabaceae & 4. Shade trees & 2,3 , and 6 & 7 \\
\hline 8 & Baddannoo & Balanites aegyptiaca & Balanitaceae & 2. Timber trees & $1,2,3$, and 4 & 3 \\
\hline 9 & Baddeessaa & Syzygium guineense & Myrtaceae & 2. Timber trees & 1,3 , and 4 & 4 \\
\hline 10 & Bahaa & Strychnos spinosa & Loganiaceae & 4. Shade trees & $3,4,5,6$, and 9 & 6 \\
\hline 11 & Bakkanniisa & Croton macrostachyus & Euphorbiaceae & 4. Shade trees & 2,6, and 9 & 22 \\
\hline 12 & Bosoqa & Sapium ellipticum & Euphorbiaceae & 2. Timber trees & $3,5,6$, and 9 & 4 \\
\hline 13 & Botoroo & $\begin{array}{l}\text { Stereospermum } \\
\text { kunthianum }\end{array}$ & Bignoniaceae & 9. Shrub & 3. Fuelwood & 13 \\
\hline 14 & Buna & Coffea arabica & Rubiaceae & 9. Cash crop & 1 and 7 & 1018 \\
\hline 15 & Burquqqee & Acacia nilotica & Fabaceae & 9. Shrub & 3. Fuelwood & 9 \\
\hline 16 & Cayii & Celtis africana & Ulmaceae & 2. Timber trees & 3 and 4 & 2 \\
\hline 17 & Ceekaa & Calpurnia aurea & Fabaceae & 9. Shrub & 3. Fuelwood & 85 \\
\hline 18 & Dambii & Ficus thonningii & Moraceae & 4. Shade trees & 3,5, and 6 & 6 \\
\hline 19 & Dhangaggoo & Rhoicissus tridentata & Vitaceae & 9. Herb & 1 and 6 & 32 \\
\hline 20 & Dhoqonuu & Grewia ferruginea & Tiliaceae & 9. Shrub, climber & 4. Construction & 16 \\
\hline 21 & Doggomaa & Croton macrostachyus & Euphorbiaceae & 2. Timber trees & 3 and 4 & 4 \\
\hline 22 & Doqoo & & & 2. Timber trees & 3,4 , and 9 & 3 \\
\hline 23 & Gatamaa/Gagamaa & Olea welwitschii & Oleaceae & 2. Timber trees & $2,3,4$, and 9 & 2 \\
\hline 24 & Geeshoo & Rhamnus prinoides & Rhamnaceae & 9. Shrub & 1 and 7 & 6 \\
\hline 25 & Gizaawwaa & Withania somnifera & Solanaceae & 9. Shrub & 2 and 3 & 3 \\
\hline 26 & Gursadee & & & 9. Shrub & 2. Medicine & 12 \\
\hline 27 & Harangamaa & Maerua aethiopica & Capparidaceae & 9. Climber & 8. Live fence & 23 \\
\hline 28 & Harbuu & Ficus sur & Moraceae & 4. Shade trees & 1,3, and 5 & 2 \\
\hline 29 & Harooressa & Grewia bicolor & Tiliaceae & 2. Timber trees & 3 and 4 & 8 \\
\hline 30 & Heexoo/Koosoo & Hagenia abyssinica & Rosaceae & 2. Timber trees & 2,3 , and 6 & 8 \\
\hline 31 & Hoomii & Prunus africana & Rosaceae & 2. Timber trees & $2,3,4$, and 7 & 3 \\
\hline
\end{tabular}


Table A4. Cont.

\begin{tabular}{|c|c|c|c|c|c|c|}
\hline S. Number & $\begin{array}{l}\text { Local Name/s of the } \\
\text { Plant/Crop Species }\end{array}$ & Scientific Name & Family Name & $\begin{array}{l}\text { Plant/Crop Typology } \\
\text { 1. Fruit trees } \\
\text { 2. Timber trees } \\
\text { 3. Forage } \\
\text { 4. Shade trees } \\
\text { 5. Root and tuber } \\
\text { 6. Vegetables } \\
\text { 7. Pulse } \\
\text { 8. Cereals } \\
\text { 9. Others, specify }\end{array}$ & $\begin{array}{l}\text { Purpose of the } \\
\text { Plants/Crops in the } \\
\text { System: } \\
\text { 1. Food } \\
\text { 2. Medicine } \\
\text { 3. Fuelwood } \\
\text { 4. Construction } \\
\text { 5. Fodder } \\
\text { 6. Soil conservation } \\
\text { 7. Income generation } \\
\text { 8. Others } \\
\text { 9. Shade }\end{array}$ & $\begin{array}{l}\text { Abundance of the } \\
\text { species in the system }\end{array}$ \\
\hline 32 & Incinnii & Sesbania sesban & Fabaceae & 9. Climber & 4 and 8 & 53 \\
\hline 33 & Indoodee & Phytolacca dodecandra & Phytolaccaceae & 9. Climber & 2. Medicine & 19 \\
\hline 34 & Kombolcha & Maytenus arbutifolia & Celastraceae & 9. Shrub & 8. Live Fence & 25 \\
\hline 35 & Kosorruu/sokorruu & Acanthus pubescens & Acanthaceae & 9. Shrub & 3. Fuelwood & 35 \\
\hline 36 & Laaftoo & Acacia sieberiana & Fabaceae & 4. Shade trees & $3,4,5,6$, and 9 & 14 \\
\hline 37 & Lolchiisaa & Bersama abyssinica & Melianthaceae & 2. Timber trees & 2,3, and 4 & 3 \\
\hline 38 & Lookoo & Diospyros abyssinica & Ebenaceae & 2. Timber trees & 2,3 , and 4 & 8 \\
\hline 39 & Oobdaa & Ficus vasta & Moraceae & 4. Shade trees & $3,5,6$, and 9 & 4 \\
\hline 40 & oogiwoo/koroolimaa & Ethiopian candimon & & 9. Spice & 7 and 8. Spice & 56 \\
\hline 41 & Qararoo & Acokanthera schimperi & Apocynaceae & 2. Timber trees & 3 and 4 & 4 \\
\hline 42 & Qolaadii & Mimusops kummel & Sapotaceae & 4. Shade trees & 3,4, and 9 & 5 \\
\hline 43 & Qomanyoo & Brucea antidysenterica & Simaroubaceae & 9. Shrub & 2 and 3 & 3 \\
\hline 44 & Reejjii & Vernonia rueppellii & Asteraceae & 4 and 9. Shrub & 3,6 , and 9 & 44 \\
\hline 45 & Rigaa arbaa & Bridelia micrantha & Euphorbiaceae & 9. Shrub & 8, brush & 12 \\
\hline 46 & Saacoo/too & Erica arborea & Ericaceae & 4. Shade trees & 3,4 , and 9 & 3 \\
\hline 47 & somboo & Ekebergia capensis & Meliaceae & 2. Timber trees & $2,3,4$, and 9 & 3 \\
\hline 48 & Sondii & Acacia lahai & Fabaceae & 4. Shade trees & $3,4,5,6$, and 9 & 7 \\
\hline 49 & Sootalloo & Millettia ferruginea & Fabaceae & 4. Shade trees & 2,3, and 6 & 7 \\
\hline 50 & Ulaagaa & Ehretia cymosa & Boraginaceae & 4. Shade trees & 2,3, and 4 & 4 \\
\hline 51 & Ulmaayii & & & 9. Shrub & $\begin{array}{l}2,3 \text {, and } 8 \text {, teeth } \\
\text { brush }\end{array}$ & 20 \\
\hline 52 & Urgeessaa & Premna schimperi & Lamiaceae & 9. Shrub & 2,3 , and 4 & 6 \\
\hline 53 & $\begin{array}{l}\text { uuyyuu/Muka } \\
\text { gurraacha }\end{array}$ & & & 2. Timber trees & 3,4 , and 9 & 2 \\
\hline 54 & Waddeessa & Cordia africana & Boraginaceae & 2 and 4 & $3,4,5,7$, and 9 & 8 \\
\hline 55 & Waleensuu & Erythrina abyssinica & Fabaceae & 9. Shrub & 3 and 4 & 6 \\
\hline 56 & Xaaxessaa & Rhus natalensis & Anacardiaceae & 9. Shrub & 2,3 , and 4 & 5 \\
\hline
\end{tabular}


Table A5. Species Compositions of Annual Crop Production System.

\begin{tabular}{|c|c|c|c|c|c|c|}
\hline S. Number & $\begin{array}{l}\text { Local Name/s of the } \\
\text { Plant/Crop Species }\end{array}$ & Scientific Name & Family Name & $\begin{array}{l}\text { Plant/Crop Typology } \\
\text { 1. Fruit trees } \\
\text { 2. Timber trees } \\
\text { 3. Forage } \\
\text { 4. Shade trees } \\
\text { 5. Root and tuber } \\
\text { 6. Vegetables } \\
\text { 7. Pulse } \\
\text { 8. Cereals } \\
\text { 9. Others, specify }\end{array}$ & $\begin{array}{l}\text { Purpose of the } \\
\text { Plants/Crops in the } \\
\text { System: } \\
\text { 1. Food } \\
\text { 2. Medicine } \\
\text { 3. Fuelwood } \\
\text { 4. Construction } \\
\text { 5. Fodder } \\
\text { 6. Soil conservation } \\
\text { 7. Income generation } \\
\text { 8. Others } \\
\text { 9. Shade }\end{array}$ & $\begin{array}{l}\text { Abundance of the } \\
\text { species in the system }\end{array}$ \\
\hline 1 & Abbayyii & Maesa lanceolata & Myrsinaceae & 4. Shade trees & $2,3,5$, and 6 & 1 \\
\hline 2 & Ambabbeessa/mukarbaa & Albizia gummifera & Fabaceae & 4. Shade trees & 9. Shade & 2 \\
\hline 3 & Baargamoo Diimaa & $\begin{array}{l}\text { Eucalyptus } \\
\text { camaldulensis }\end{array}$ & Myrtaceae & & & 3 \\
\hline 4 & Bahaa & Strychnos spinosa & Loganiaceae & 4. Shade trees & $3,4,5,6$, and 9 & 4 \\
\hline 5 & Bakkanniisa & Croton macrostachyus & Euphorbiaceae & 4. Shade trees & 2,6 , and 9 & 7 \\
\hline 6 & Barbaree & Capsicum аппиит & Solanaceae & & & 176 \\
\hline 7 & Boqqolloo & Zea mays & Poaceae & 8. Cereals & 1. Food & 14850 \\
\hline 8 & Bosoqa & Sapium ellipticum & Euphorbiaceae & 2. Timber trees & $3,5,6$, and 9 & 1 \\
\hline 9 & Botoroo & $\begin{array}{l}\text { Stereospermum } \\
\text { kunthianum }\end{array}$ & Bignoniaceae & 9. shrub & 3. Fuelwood & 1 \\
\hline 10 & Buna & Coffea arabica & Rubiaceae & 9. Cash crop & 1. Food & 40 \\
\hline 11 & Burtukaana & Citrus sinensis & Rutaceae & 9 & & 1 \\
\hline 12 & Caatii & Catha edulis & Celastraceae & 9 & & 6 \\
\hline 13 & Cadaa & Euphorbia tirucalli & Euphorbiaceae & & & 33 \\
\hline 14 & Dabaaqula/Buqqee & Dabaaqula/Buqqee & Cucurbita pepo & & & 4 \\
\hline 15 & Dafee/Boloqqee & Phaseolus vulgaris & Fabaceae & & & 477 \\
\hline 16 & Dambii & Ficus thonningi & Moraceae & 4. Shade trees & 3,5 , and 6 & 1 \\
\hline 17 & Dhangaggoo & Rhoicissus tridentata & Vitaceae & 9. Herb & 1 and 6 & 16 \\
\hline 18 & Dinnicha Oromoo & Plectranthus edulis & Lamiaceae & & & 13 \\
\hline 19 & Eebicha & $\begin{array}{c}\text { Vernonia } \\
\text { amygdalina/schimperi }\end{array}$ & Asteraceae & 3. Forage & $2,3,5$, and 6 & 9 \\
\hline 20 & Geeshoo & Rhamnus prinoides & Rhamnaceae & 9. Shrub & 1 and 7 & 5 \\
\hline 21 & $\begin{array}{c}\text { Giraaviiliyaa/Muka } \\
\text { Oawwee }\end{array}$ & Grevillea robusta & Proteaceae & & & 26 \\
\hline 22 & Harangamaa & Maerua aethiopica & Capparidaceae & 9. Climber & 8. Live fence & 3 \\
\hline
\end{tabular}


Table A5. Cont.

\begin{tabular}{|c|c|c|c|c|c|c|}
\hline S. Number & $\begin{array}{l}\text { Local Name/s of the } \\
\text { Plant/Crop Species }\end{array}$ & Scientific Name & Family Name & $\begin{array}{l}\text { Plant/Crop Typology } \\
\text { 1. Fruit trees } \\
\text { 2. Timber trees } \\
\text { 3. Forage } \\
\text { 4. Shade trees } \\
\text { 5. Root and tuber } \\
\text { 6. Vegetables } \\
\text { 7. Pulse } \\
\text { 8. Cereals } \\
\text { 9. Others, specify }\end{array}$ & $\begin{array}{l}\text { Purpose of the } \\
\text { Plants/Crops in the } \\
\text { System: } \\
\text { 1. Food } \\
\text { 2. Medicine } \\
\text { 3. Fuelwood } \\
\text { 4. Construction } \\
\text { 5. Fodder } \\
\text { 6. Soil conservation } \\
\text { 7. Income generation } \\
\text { 8. Others } \\
\text { 9. Shade }\end{array}$ & $\begin{array}{l}\text { Abundance of the } \\
\text { species in the system }\end{array}$ \\
\hline 23 & Harbuu & Ficus sur & Moraceae & 4. Shade trees & 1,3 , and 5 & 1 \\
\hline 24 & Hoomii & Prunus africana & Rosaceae & 2. Timber trees & $2,3,4$, and 7 & 2 \\
\hline 25 & Indoodee & Phytolacca dodecandra & Phytolaccaceae & & & 10 \\
\hline 26 & Kaashimiirii & Conyza stricta & Asteraceae & & & 1 \\
\hline 27 & Laaftoo & Acacia sieberiana & Fabaceae & 4. Shade trees & $3,4,5,6$, and 9 & 2 \\
\hline 28 & Lolchiisaa & Bersama abyssinica & Melianthaceae & 2. Timber trees & 2,3, and 4 & 1 \\
\hline 29 & Loomii & Citrus aurantiifolia & Rutaceae & & & 1 \\
\hline 30 & Maangoo & Mangifera indica & Anacardiaceae & & & 5 \\
\hline 31 & Marga Veetiivaar & & & & & 33 \\
\hline 32 & Mishingaa & Sorghum bicolor & Poaceae & 8. Cereals & 1. Food & 2218 \\
\hline 33 & Mixaaxisa & Ipomoea batatas & Convolvulaceae & 5. Root and tuber & 1 and 7 & 34 \\
\hline 34 & Muuzii & Musa acuminata & Musaceae & & & 7 \\
\hline 35 & Oobdaa & Ficus vasta & Moraceae & 4. Shade trees & $3,5,6$, and 9 & 2 \\
\hline 36 & Paappayyaa & Carica papaya & Caricaceae & & & 3 \\
\hline 37 & Qobboo & Ricinus communis & Euphorbiaceae & & & 7 \\
\hline 38 & Qomanyoo & Brucea antidysenterica & Simaroubaceae & 9. Shrub & 2 and 3 & 1 \\
\hline 39 & Raafuu Habashaa & Brassica carinata & Brassicaceae & & & 66 \\
\hline 40 & Reejjii & Vernonia rueppellii & Asteraceae & 4 and 9. Shrub & 3,6 , and 9 & 7 \\
\hline 41 & Sasbaaniyaa & Sesbania sesban & Fabaceae & & & 11 \\
\hline 42 & somboo & Ekebergia capensis & Meliaceae & 2. Timber trees & $2,3,4$, and 9 & 1 \\
\hline 43 & Sondii & Acacia lahai & Fabaceae & 4. Shade trees & $3,4,5,6$, and 9 & 1 \\
\hline 44 & Sootalloo & Millettia ferruginea & Fabaceae & 4. Shade trees & 2,3, and 6 & 2 \\
\hline 45 & Waddeessa & Cordia africana & Boraginaceae & 2 and 4 & $3,4,5,7$, and 9 & 4 \\
\hline 46 & Waleensuu & Erythrina abyssinica & Fabaceae & 9. Shrub & 3 and 4 & 1 \\
\hline 47 & Zayituunaa & Psidium guajava & Myrtaceae & 1. Fruit trees & 1 and 7 & 3 \\
\hline
\end{tabular}




\section{References}

1. Liang, W. Farming systems as an approach to agro-ecological engineering. Ecol. Eng. 1998, 11, 27-35. [CrossRef]

2. Global Agricultural Productivity Report; Global Harvest Initiative: Washington, DC, USA, 2016.

3. Coetzer, K.L.; Witkowski, E.T.; Erasmus, B.F. Reviewing B iosphere R eserves globally: Effective conservation action or bureaucratic label? Boil. Rev. 2014, 89, 82-104. [CrossRef] [PubMed]

4. Prip, C. The Convention on Biological Diversity as a legal framework for safeguarding ecosystem services. Ecosyst. Serv. 2018, 29, 199-204. [CrossRef]

5. Gatzweiler, F.; Reichhuber, A.; Hein, L. Why Financial Incentives Can Destroy Economically Valuable Biodiversity in Ethiopia; ZEF Discussion Papers on Development Policy; University of Bonn, Center for Development Research (ZEF): Bonn, Germany, 2007.

6. Young, J. Ethiopian Protected Areas: A "Snapshot"; A Reference Guide for Future Strategic Planning and Project Funding. Available online: https:/ / phe-ethiopia.org/admin/uploads/attachment-1167 (accessed on 2 April 2012).

7. Ango, T.G.; Börjeson, L.; Senbeta, F.; Hylander, K. Balancing ecosystem services and disservices: Smallholder farmers' use and management of forest and trees in an agricultural landscape in southwestern Ethiopia. Ecol. Soc. 2014, 19. [CrossRef]

8. Senbeta, F.; Gole, T.W.; Denich, M.; Kellbessa, E. Diversity of useful plants in the coffee forests of Ethiopia. Ethnobot. Res. Appl. 2013, 11, 49-69.

9. Gole, T.W.; Feyera, S.; Kassahun, T.; Fite, G. Yayu Coffee Forest Biosphere Reserve Nomination Form; Ethiopian MAB National Committee: Addis Ababa, Ethiopia, 2009.

10. Environment and Coffee Forest Forum Report; Unpublished Report; Addis Ababa, Ethiopia, 2016.

11. Yakob, G.; Fekadu, A. Diversity and Regeneration Status of Woody Species: The Case of Keja Araba and Tula Forests, South West Ethiopia. Open Access Libr. J. 2016, 3, 1. [CrossRef]

12. Gole, T.W. Vegetation of the Yayu Forest in SW Ethiopia: Impacts of Human Use and Implications for In Situ Conservation of Wild Coffea arabica, L. Populations; Cuvillier: Göttingen, Germany, 2003.

13. Jerneck, A.; Olsson, L. More than trees! Understanding the agroforestry adoption gap in subsistence agriculture: Insights from narrative walks in Kenya. J. Rural Stud. 2013, 32, 114-125. [CrossRef]

14. Chiarucci, A.; De Dominicis, V.; Wilson, J.B. Structure and floristic diversity in permanent monitoring plots in forest ecosystems of Tuscany. For. Ecol. Manag. 2001, 141, 201-210. [CrossRef]

15. Kothari, C.R. Research Methodology: Methods and Techniques; New Age International: New Delhi, India, 2004.

16. Assessment, M.E. Millennium ecosystem assessment. Ecosystems and Human Well-Being: Biodiversity Synthesis; World Resources Institute: Washington, DC, USA, 2005.

17. Bateman, I.J.; Harwood, A.R.; Abson, D.J.; Andrews, B.; Crowe, A.; Dugdale, S.; Fezzi, C.; Foden, J.; Hadley, D.; Haines-Young, R.; et al. Economic analysis for the UK national ecosystem assessment: Synthesis and scenario valuation of changes in ecosystem services. Environ. Resour. Econ. 2014, 57, 273-297. [CrossRef]

18. Muhamad, D.; Okubo, S.; Harashina, K.; Gunawan, B.; Takeuchi, K. Living close to forests enhances people's perception of ecosystem services in a forest-agricultural landscape of West Java, Indonesia. Ecosyst. Serv. 2014, 8, 197-206. [CrossRef]

19. Gole, T.W.; Borsch, T.; Denich, M.; Teketay, D. Floristic composition and environmental factors characterizing coffee forests in southwest Ethiopia. For. Ecol. Manag. 2008, 255, 2138-2150. [CrossRef]

20. Aerts, R.; Hundera, K.; Berecha, G.; Gijbels, P.; Baeten, M.; Van Mechelen, M.; Hermy, M.; Muys, B.; Honnay, O. Semi-forest coffee cultivation and the conservation of Ethiopian Afromontane rainforest fragments. For. Ecol. Manag. 2011, 261, 1034-1041. [CrossRef]

21. Burkhard, B.; Müller, A.; Müller, F.; Grescho, V.; Anh, Q.; Arida, G.; Bustamante, J.V.; Van Chien, H.; Heong, K.L.; Escalada, M.; et al. Land cover-based ecosystem service assessment of irrigated rice cropping systems in southeast Asia-An explorative study. Ecosyst. Serv. 2015, 14, 76-87. [CrossRef]

22. Jackson, L.E.; Pascual, U.; Hodgkin, T. Utilizing and conserving agrobiodiversity in agricultural landscapes. Agric. Ecosyst. Environ. 2007, 121, 196-210. [CrossRef]

23. Garbach, K.; Milder, J.C.; Montenegro, M.; Karp, D.S.; DeClerck, F.A. Biodiversity and ecosystem services in agroecosystems. Encycl. Agric. Food Syst. 2014, 2, 21-40. 
24. OECD. OECD-Work on Biodiversity and Ecosystems. 2014. Available online: www.oecd.org/env/ biodiversity (accessed on 17 June 2017).

25. Cassano, C.R.; Barlow, J.; Pardini, R. Forest loss or management intensification? Identifying causes of mammal decline in cacao agroforests. Boil. Conserv. 2014, 169, 14-22. [CrossRef]

26. Jellinek, S.; Rumpff, L.; Driscoll, D.A.; Parris, K.M.; Wintle, B.A. Modelling the benefits of habitat restoration in socio-ecological systems. Boil. Conserv. 2014, 169, 60-67. [CrossRef]

27. West, P.C.; Gibbs, H.K.; Monfreda, C.; Wagner, J.; Barford, C.C.; Carpenter, S.R.; Foley, J.A. Trading carbon for food: Global comparison of carbon stocks vs. crop yields on agricultural land. Proc. Natl. Acad. Sci. USA 2010, 107, 19645-19648. [CrossRef] [PubMed]

28. Abebe, T.; Sterck, F.J.; Wiersum, K.F.; Bongers, F. Diversity, composition and density of trees and shrubs in agroforestry homegardens in Southern Ethiopia. Agrofor. Syst. 2013, 87, 1283-1293. [CrossRef]

29. Brandt, P.; Abson, D.J.; DellaSala, D.A.; Feller, R.; von Wehrden, H. Multifunctionality and biodiversity: Ecosystem services in temperate rainforests of the Pacific Northwest, USA. Boil. Conserv. 2014, 169, 362-371. [CrossRef]

30. Mace, G.M.; Norris, K.; Fitter, A.H. Biodiversity and ecosystem services: A multilayered relationship. Trends Ecol. Evol. 2012, 27, 19-26. [CrossRef] [PubMed]

(C) 2019 by the authors. Licensee MDPI, Basel, Switzerland. This article is an open access article distributed under the terms and conditions of the Creative Commons Attribution (CC BY) license (http:/ / creativecommons.org/licenses/by/4.0/). 